\title{
The response of the Rhizobium leguminosarum bv. trifolii wild-type and exopolysaccharide-deficient mutants to oxidative stress
}

\author{
Magdalena Jaszek • Monika Janczarek • \\ Krzysztof Kuczyński • Tomasz Piersiak • \\ Krzysztof Grzywnowicz
}

Received: 21 March 2013 / Accepted: 21 October 2013 / Published online: 14 November 2013

(C) The Author(s) 2013. This article is published with open access at Springerlink.com

\begin{abstract}
Aims The aim of this study was investigation of the response of $R$. leguminosarum bv. trifolii wild-type and its two $\operatorname{ros} R$ and $p s s A$ mutant strains impaired in exopolysaccharide (EPS) synthesis to oxidative stress conditions caused by two prooxidants: a superoxide anion generator- menadione (MQ) and hydrogen peroxide $\left(\mathrm{H}_{2} \mathrm{O}_{2}\right)$.

Methods The levels of enzymatic (catalase, superoxide dismutase, pectinase and $\beta$-glucosidase) and nonenzymatic (superoxide anion generator, formaldehyde, phenolic compounds) biomarkers were monitored using biochemical methods in both the supernatants and rhizobial cells after treatment with $0.3 \mathrm{mM}$ MQ and $1.5 \mathrm{mM}$
\end{abstract}

Responsible Editor: Katharina Pawlowski.

M. Janczarek $(\bowtie)$

Department of Genetics and Microbiology,

Maria Curie-Skłodowska University,

Akademicka 19, 20-033 Lublin, Poland

e-mail: mon.jan@poczta.umcs.lublin.pl

M. Jaszek $\cdot$ K. Kuczyński $\cdot$ K. Grzywnowicz

Department of Biochemistry, Maria Curie-Skłodowska

University,

Akademicka 19, 20-033 Lublin, Poland

T. Piersiak

Department of Comparative Anatomy and Anthropology,

Maria Curie-Skłodowska University,

Akademicka 19, 20-033 Lublin, Poland

T. Piersiak

Chair and Department of Medicinal Chemistry,

Medical University of Lublin,

Jaczewskiego 4, 20-090 Lublin, Poland
$\mathrm{H}_{2} \mathrm{O}_{2}$. The viability of bacterial cells was estimated using fluorescent dyes and confocal laser scanning microscopy. In addition, the effect of prooxidants on symbiosis of the $R$. leguminosarum bv. trifolii strains with clover was established.

Results The tested stress factors significantly changed enzymatic patterns of the rhizobial strains, and the wildtype strain proved to be more resistant to these prooxidants than both pssA and $\operatorname{ros} R$ mutants. Significantly higher activities of both catalase and superoxide dismutase have been detected in these mutants in comparison to the wildtype strain. $\mathrm{H}_{2} \mathrm{O}_{2}$ and MQ also increased the levels of pectinase and $\beta$-glucosidase activities in the tested strains. Moreover, pre-incubation of $R$. leguminosarum bv. trifolii strains with the prooxidants negatively affected the viability of bacterial cells and the number of nodules elicited on clover plants.

Conclusions EPS produced in large amounts by $R$. leguminosarum bv. trifolii plays a significant protective role as a barrier against oxidative stress factors and during symbiotic interactions with clover plants.

Keywords Rhizobium leguminosarum bv. trifolii $\cdot$ pss A and $r o s R$ genes · EPS-deficient mutants · Oxidative stress response $\cdot$ Exopolysaccharide production $\cdot$ Effectiveness of symbiosis

\section{Introduction}

Rhizobium leguminosarum bv. trifolii is an aerobic gram-negative bacterium that can live free in the soil 
or establish a symbiosis with roots of clover plants (Trifolium pratense) (McIntyre et al. 2007). During this process, a sophisticated exchange of recognition signals occurs between both symbiotic partners (Gibson et al. 2008). In response to flavonoids secreted by legume roots, rhizobia synthesize nodulation factors, which are essential for formation of specialized new organs on roots called nodules. Inside nodule cells, bacteria differentiate into their symbiotic forms - bacteroids, which reduce atmospheric nitrogen to ammonia (Gibson et al. 2008). Nitrogenase, a key enzyme of nitrogen fixation, is inactivated rapidly and irreversibly by oxygen. Leghemoglobin occurring in the cortex of nodules constitutes a diffusion barrier that limits permeability to oxygen and prevents the activity of this enzyme. Although this system efficiently reduces the excess of oxygen diffused to nodule cells, a high rate of respiration providing energy for the nitrogen reduction process generates reactive oxygen species (ROS) such as superoxide anion radicals (SOR) and hydrogen peroxide $\left(\mathrm{H}_{2} \mathrm{O}_{2}\right)$ (Santos et al. 2001). Additionally, rhizobia living in soil and in the rhizosphere of other plants are exposed to oxidative stress factors. The response of both freeliving bacteria and bacteroids to the toxic form of oxygen is an important factor for nodulation and nitrogen fixation. Reactive oxygen species also play a key role as central signal molecules acting in plant adaptation to both biotic and abiotic stresses (Hérouart et al. 2002). Increased levels of ROS enable plants to control and block pathogen penetration (Orikasa et al. 2010). Because pathogenesis and symbiosis are a variation on a common theme, rhizobia are at first recognized as intruders and generation of oxidative burst in host cells is observed (Baron and Zambryski 1995). In order to establish legume-rhizobium symbiosis, there is a special mechanism whereby the typical host defence elements are suppressed. There are many examples showing accumulation of ROS during infection of leguminous plants by rhizobia (Ramu et al. 2002; Pauly et al. 2006). It has also been proposed that reactive oxygen species can stimulate expression of plant and/or bacterial genes that are significant for nodule formation (Hérouart et al. 2002).

Thus, both during progression of symbioses and during life inside formed nodules, rhizobia are exposed to the action of various stress factors including prooxidants. In response to changing environmental conditions, rhizobia have evolved an efficient defence system to inactivate different free radical derivatives including superoxide anion radicals, hydrogen peroxide, or extremely reactive hydroxyl radicals. Using enzymatic and non-enzymatic antioxidants, these microorganisms can keep a physiologically safe level of ROS throughout the exponential and stationary phases of growth and during the interaction with plants (Matamoros et al. 2003). An investigation of the role of superoxide radicals and $\mathrm{H}_{2} \mathrm{O}_{2}$ in alfalfa-Sinorhizobium meliloti symbiosis showed the presence of such ROS at early stages of the infection process and during the development of infection threads (Santos et al. 2000). Absence of $\mathrm{H}_{2} \mathrm{O}_{2}$ inside bacterial cells and bacteroids suggests the action of effective antioxidative mechanisms in rhizobia (Hérouart et al. 2002). One of the enzymes which plays a major role in protection of oxidative cell homeostasis in bacteria is superoxide dismutase (SOD), a metalloenzyme catalysing dismutation of $\mathrm{O}_{2}^{-}$to $\mathrm{H}_{2} \mathrm{O}_{2}$ and $\mathrm{O}_{2}$ (Santos et al. 2000; Saenkham et al. 2007). Hydrogen peroxide, the product of dismutation, is degraded by catalases (CAT), which play a crucial role in the symbiosis during both host plant infection and nitrogen fixation processes (Orikasa et al. 2010).

In addition, cell surface polysaccharides of rhizobia, including exopolysaccharides (EPS) and lipopolysaccharides (LPS), play a key role in both adaptation to environmental conditions and establishment of effective symbioses with leguminous plants (Downie 2010; Mathis et al. 2005). EPS performs several functions, such as nutrient gathering, protection against stress factors and antimicrobial compounds, biofilm formation, and attachment to abiotic surfaces and host plant roots. Moreover, this polysaccharide is a suppressor of the host plant defence reaction, and its low-molecular-weight fraction plays a specific role as a signal molecule in the symbiotic dialogue (Janczarek 2011). EPSdeficient mutants of Rhizobium leguminosarum and Sinorhizobium meliloti are impaired in invasion of nodule cells and nitrogen fixation (Rolfe et al. 1996; Cheng, and Walker 1998). EPS of R. leguminosarum. bv. trifolii is a heteropolymer composed of repeating units containing five glucose, one galactose and two glucuronic acid residues, modified by acetyl, pyruvyl, and 3hydroxybutanoyl groups (Janczarek 2011).

Two pss $A$ and $\operatorname{ros} R$ genes play a key role in EPS production in $R$. leguminosarum (Janczarek et al. 2009b). pssA encodes a glucosyl-IP-transferase involved in the first step of EPS synthesis and a mutation in this gene results in a total lack of production of this polymer. $\operatorname{ros} R$ encodes a transcriptional regulator 
involved in positive regulation of this process and its mutation substantially (3-fold) decreases the amount of produced EPS (Janczarek and Skorupska 2007; Janczarek et al. 2009a). Both mutants induce formation of small nodules on clover plants that are unable to fix nitrogen. Moreover, the rosR mutant shows several other pleiotropic effects such as increased sensitivity to surface-active detergents and some osmolytes, changes in extracellular and membrane protein profiles, and decreased ability to infect roots of the host plant, indicating that the product of this gene is involved in the adaptation of $R$. leguminosarum bv. trifolii to stress conditions (Janczarek et al. 2010). On the other hand, multiple copies of $\operatorname{ros} R$ and pss $A$ genes significantly enhance EPS production and the number of nodules induced on clover roots (Janczarek et al. 2009a). The expression of these genes is affected by phosphate and clover root exudates (Janczarek and Skorupska 2011).

Up to now, there are no data concerning mechanisms of oxidative stress response in $R$. leguminosarum bv. trifolii, therefore the aim of this study was to investigate the effects of two prooxidants, menadione (2-methyl1,4-naphtoquinone; MQ) and $\mathrm{H}_{2} \mathrm{O}_{2}$, on chosen enzymatic (catalase and superoxide dismutase activities) and non-enzymatic (superoxide anion radicals, formaldehyde, and phenolic compounds) biomarkers related to antioxidative defence. MQ is a redox-cycling compound commonly used as a SOR-generator (Saenkham et al. 2007). These prooxidants were chosen because large amounts of SOR and $\mathrm{H}_{2} \mathrm{O}_{2}$ are present in infection threads and these ROS species are related to active oxygen derivatives produced by plants during the oxidative burst phenomenon. We investigated how bacteria of $R$. leguminosarum bv. trifolii species respond to $\mathrm{H}_{2} \mathrm{O}_{2}$ - and MQ-mediated oxidative stress when exposed to a low concentration of these compounds for a relatively long incubation period.

Moreover, because hydrolytic enzymes were found to be important for proper infection of host plants by rhizobia, the activities of pectinase (PEC) and $\beta$ glucosidase $(\beta-\mathrm{GLU})$ were also estimated (Lum and Hirsch 2003; Mateos et al. 1992). To investigate the possible role of EPS in $R$. leguminosarum bv. trifolii antioxidative defence mechanisms, both pss $A$ and $\operatorname{ros} R$ mutants have been included in these experiments. The present study also evaluates the efficiency of the investigated strains in development of symbiotic interactions with clover using bacteria after pre-treatment with the prooxidants.

\section{Materials and methods}

Strains, media, and growth conditions

R. leguminosarum bv. trifolii wild-type strain Rt 24.2 and its two rosR (Rt2472) and pss A (Rt5819) mutants were tested for their sensitivity to chosen prooxidants $\left(\mathrm{H}_{2} \mathrm{O}_{2}\right.$ and MQ). The bacterial strains used in this study have been described in details in a previous paper (Janczarek et al. 2009a). Rt24.2 and its derivatives were grown in tryptone-yeast (TY) medium at $28{ }^{\circ} \mathrm{C}$ (Sambrook et al. 1989). When required, antibiotics were used at the following final concentrations: kanamycin $40 \mu \mathrm{g} \mathrm{mL}^{-1}$ and nalidixic acid $40 \mu \mathrm{g} \mathrm{mL} \mathrm{m}^{-1}$. To study the influence of the prooxidants on the growth of rhizobial strains, different concentrations of $\mathrm{H}_{2} \mathrm{O}_{2}(0-3 m M)$ and menadione $(0-3 m M)$ were tested. The viability of cells from these cultures was established by spotting $15-\mu$ l aliquots onto TY agar plates and incubation at $28^{\circ} \mathrm{C}$ for 3 days. To study the sensitivity of these strains to the prooxidants, different concentrations of $\mathrm{H}_{2} \mathrm{O}_{2}$ and MQ (up to $3 \mathrm{mM}$ ) were added to 48 -h cultures and the incubation was continued up to $6 \mathrm{~h}$. After each $30 \mathrm{~min}, 15-\mu \mathrm{l}$ aliquots of the cultures were spotted on the plates and bacterial growth was monitored during 3 days.

The effect of EPS on survival of rosR and pssA mutant cells in the presence of prooxidants

To study the influence of EPS on survival of the rosR and psSA mutants in the presence of prooxidants, bacteria of these mutants and the wild-type strain were grown in $5 \mathrm{ml} \mathrm{TY}$ medium at $28^{\circ} \mathrm{C}$ for $24 \mathrm{~h}$. Then, the optical density $\mathrm{OD}_{600}$ of the cultures was measured and equalized with TY to 0.4. For this experiment, two Rt5819/Rt24.2 and Rt2472/Rt24.2 mixtures containing equal ratios of the mutant culture and the wild-type strain culture were used. In addition, cultures of the Rt24.2, Rt2472 and Rt5819 strains of $\mathrm{OD}_{600}=0.2$ were used as controls. 10- $\mu$ l aliquots of these bacterial cultures and the mixtures were spotted on TY plates containing different concentrations of MQ $(0-1 \mathrm{mM})$ and $\mathrm{H}_{2} \mathrm{O}_{2}(0-3 m M)$. In order to eliminate the growth of the Rt24.2 cells present in the Rt5819/Rt24.2 and Rt2472/Rt24.2 mixtures, kanamycin was added into agar medium (the Rt5819 and Rt2472 mutant strains are kanamycin-resistant). The plates were incubated at 
$28^{\circ} \mathrm{C}$ and after 3 days bacterial growth was estimated. Three independent experiments were performed in triplicate for each bacterial mixture and culture tested.

Preparation of biological samples

To establish the influence of the oxidants on enzymatic and non-enzymatic parameters of the tested $R$. leguminosarum bv. trifolii strains, the bacteria were grown in $450 \mathrm{ml} \mathrm{TY}$ medium at $28{ }^{\circ} \mathrm{C}$ for 2 days with rotary shaking $(120 \mathrm{rpm})$ to $\mathrm{OD}_{600}$ of 0.8 . Then, MQ and hydrogen peroxide were added to the final concentrations of $0.3 \mathrm{mM}$ and $1.5 \mathrm{mM}$, respectively, and the incubation was continued during $3 \mathrm{~h}$. Subsequently, the cultures were centrifuged at $6,000 \times \mathrm{g}$ for $20 \mathrm{~min}$ at $4{ }^{\circ} \mathrm{C}$, and the supernatants and bacterial pellets obtained were used for further experiments.

In order to obtain bacterial extracts, the cell pellets were resuspended in $1 \mathrm{ml}$ of ice-cold MilliQ water and sonicated (six times during $30 \mathrm{~s}$, one pulse per s) on ice following the conditions described by Hérouart et al. (1996). After sonication, the extracts were centrifuged at $10,000 \times g$ for $15 \mathrm{~min}$ at $4{ }^{\circ} \mathrm{C}$. The clarified extracts were divided into portions and frozen at $-70{ }^{\circ} \mathrm{C}$.

\section{Enzyme assays}

\section{Superoxide dismutase (SOD)}

The activity of SOD was assayed in both culture supernatants and intracellular fractions using the complete set for SOD determination according to manufacturer's instruction (kit for micro-method, Sigma, St. Louis, USA). Superoxide anion radicals were produced by the xanthine oxidase reaction and oxidized with water-soluble tetrazolium salt, WST-1 (2-(4iodophenyl)-3-(4-nitrophenyl)-5-(2,4-disulfophenyl)$2 \mathrm{H}$-tetrazolium, monosodium salt, which produces a water-soluble formazan dye upon reduction with SOR. The rates of the reduction with SOR are linearly related to the xanthine oxidase activity, and are inhibited by SOD (Beauchamp and Fridovich 1970). Absorbance was measured at $440 \mathrm{~nm}$ using the BioTek Microplates Reader and the specific activity of SOD was expressed in $U$ per $\mathrm{mg}$ of protein contained in the tested sample.

\section{Catalase (CAT)}

Catalase activity was determined according to the method provided by Aebi (1984). Calculation of CAT activity was based on the amount of hydrogen peroxide decomposed by the enzyme during the incubation time $(30 \mathrm{~s})$. The changes in absorbance were recorded at $240 \mathrm{~nm}$. The specific activity of catalase was calculated in $\mu$ katals per $\mathrm{mg}$ of protein contained in the sample.

\section{Pectinase (PEC)}

Pectinolytic activity in cell-free culture supernatants was determined using $1 \%$ solution of pectin in 50 $m M$ citrate buffer ( $\mathrm{pH} 4.8$ ) as a reaction substrate. A $0.5-\mathrm{ml}$ sample was mixed with $0.5 \mathrm{ml}$ of $1 \%$ pectin and incubated for $30 \mathrm{~min}$ at $40{ }^{\circ} \mathrm{C}$ and then, the amounts of liberated reducing sugars were quantified. The concentration of sugars was evaluated using the Lloyd and Whelan method (Lloyd and Whelan 1969). Absorbance was recorded at $520 \mathrm{~nm}$ and compared with the calibration curve. One unit of pectinase activity (U) was described as the amount of the enzyme that released $1 \mu M$ galactouronic acid per min under the experimental conditions. The specific activity of pectinase was calculated in $U$ per $\mathrm{mg}$ of protein contained in the sample.

\section{$\beta$-Glucosidase ( $\beta$-GLU)}

The synthetic substrate $\mathrm{p}$-nitrophenyl- $\beta$-Dglucopyranoside (p-NPG) was used to detect $\beta$ glucosidase activity, according to the procedure described by Mitchell et al. (1986). Samples of culture supernatants were analysed for this enzymatic activity. At first, $0.75 \mathrm{ml}$ of $10 \mathrm{mM}$ p-NPG in $50 \mathrm{mM}$ citrate buffer ( $\mathrm{pH} 4.8$ ) was added to test tubes. Afterwards, $0.05 \mathrm{ml}$ of the supernatant and $0.425 \mathrm{ml}$ of deionized water was added, and the reaction mixtures were incubated at $30{ }^{\circ} \mathrm{C}$ for $30 \mathrm{~min}$. Then, the reaction was stopped by addition of $3 \mathrm{ml}$ of $0.5 \mathrm{M}$ sodium carbonate. The amount of the released product (p-nitrophenol) was determined by spectrophotometric measurement of absorbance at $420 \mathrm{~nm}$. A unit of enzyme activity (U) was expressed as the amount of $\beta$-glucosidases, which liberates $1 \mu \mathrm{M}$ p-nitrophenol per min under the experimental conditions. The specific activity of $\beta$-GLU was calculated in $\mathrm{U}$ per $\mathrm{mg}$ of protein contained in the analysed sample. 
Determination of non-enzymatic components

\section{Relative level of superoxide anion radicals (SOR)}

The measurement of the level of SOR was done according to the method described previously (PaździochCzochra et al. 2003). The relative level of SOR was measured spectrophotometrically by detection of superoxide-dependent formation of formazone from nitrotetrazolium blue (NBT) in the alkaline conditions. The reaction mixture contained $3 \mathrm{ml}$ of distilled water, $0.05 \mathrm{ml}$ of $1 M \mathrm{NaOH}, 0.1 \mathrm{ml}$ of $5 \mathrm{mM} \mathrm{NBT}$, and $0.1 \mathrm{ml}$ of the sample. After incubation for $30 \mathrm{~min}$ at room temperature, absorbance at $560 \mathrm{~nm}$ was measured. It was observed that the stabilization of SOR in the alkaline conditions prevented precipitation of dark-blue formazone within about $40 \mathrm{~min}$.

\section{Formaldehyde (FA)}

The formaldehyde concentration was determined spectrofluorimetrically with Nash reagent (excitation= $410 \mathrm{~nm}$, emission=510 nm) using the FluoroMax-2 equipment (Rapoport et al. 1994). The changes in the emission were measured after 10-min incubation at $60{ }^{\circ} \mathrm{C}$ and compared with the calibration curve.

\section{Phenolic compounds (PHC)}

The concentration of phenolic compounds (hydroxyl-, metoxyl-phenolic acids) was determined with diazosulfanilamide (SA) using the DASA test (Malarczyk 1989). The reaction mixture contained $0.1 \mathrm{ml}$ of SA $(1 \% \mathrm{SA}$ in $10 \% \mathrm{HCl}), 0.1 \mathrm{ml}$ of $5 \%$ $\mathrm{NaNO}_{2}$ solution, and $0.1 \mathrm{ml}$ of the sample. Each sample was stirred thoroughly and neutralized by addition of $1 \mathrm{ml}$ of $20 \% \mathrm{Na}_{2} \mathrm{CO}_{3}$. Absorbance was recorded at $500 \mathrm{~nm}$ and compared with the calibration curve $\left(y=6.85 \mathrm{x}-0.0218, R^{2}=0.999\right)$.

\section{Chemiluminometric detection of hydrogen peroxide}

The concentration of $\mathrm{H}_{2} \mathrm{O}_{2}$ in bacterial extracts was determined using the chemiluminescent method developed by Perez and Rubio (2006) based on the luminescence of luminol. In this method, ferricyanide used in the earlier methodology (Warm and Laties 1982) was replaced by $\mathrm{Co}$ (II), which is a catalyst for the reaction of luminol with $\mathrm{H}_{2} \mathrm{O}_{2}$, what significantly increased the sensitivity of detection. The stock solution was prepared by mixing $10 \mathrm{ml}$ of a $6.5 \mathrm{mM}$ solution of luminol in carbonate buffer $\mathrm{pH} 10.2$ with $2 \mathrm{ml}$ of $0.55 \mu M \mathrm{CoCl}_{2}$ in the same buffer. The prepared reagent was diluted 10fold after $1 \mathrm{~h}$ and was ready to use after $12 \mathrm{~h}$. The signals from the $\mathrm{Co}(\mathrm{II})-\mathrm{H}_{2} \mathrm{O}_{2}-$ luminol reaction were detected by a Lumat LB 9506 luminometer (Berthold, Germany). The peak values were recorded and compared with the calibration curve prepared for the different concentrations of $\mathrm{H}_{2} \mathrm{O}_{2}$. The amount of $\mathrm{H}_{2} \mathrm{O}_{2}$ in the bacterial extracts was expressed as $\mu \mathrm{g}$ per $\mathrm{mg}$ of proteins contained in the analysed sample.

\section{Protein concentration assay}

The protein concentration was determined with the Coomassie brilliant blue (G-250) dye-binding method (Bradford 1976) using a Bio-Rad dye stock solution with bovine serum albumin as the standard. All parameters presented in the paper refer to the protein concentration in the sample.

Visualization of intracellular SOD and CAT activity using native PAGE electrophoresis

Bacterial clarified extracts obtained after sonication and centrifugation were concentrated and separated by ultrafiltration using the Microcon Centrifugal Filter Units, 3000 NMWL designed by Millipore. Subsequently, $15 \mu \mathrm{g}$ of proteins from the samples were introduced into each well of $12.5 \%$ native polyacrylamide gel. The gels were run at $4{ }^{\circ} \mathrm{C}$ and $145 \mathrm{~V}$. After protein separation, SOD activities were visualized according to the method of Bayer and Fridovich (1987). The bands representing CAT activity were located using the ferricyanide negative stain as described by Wayne and Diaz (1986).

Determination of cell viability of rhizobial strains using confocal laser scanning microscopy

In order to determine the viability of rhizobial cells after the treatment with the prooxidants, bacteria of the wildtype and the pss $A$ and $r o s R$ mutant strains were grown in TY medium at $28^{\circ} \mathrm{C}$ for $48 \mathrm{~h}$ (3 6-ml cultures for each strain were prepared). $\mathrm{OD}_{600}$ of each culture was measured and equalized with TY medium to 0.4 . Next, the cultures were divided into three 2-ml portions. The first ones were used as control cultures, whereas $1.5 \mathrm{mM}$ $\mathrm{H}_{2} \mathrm{O}_{2}$ and $0.3 m M$ MQ were added to the second and 
to the third portions, respectively, and the incubation was continued during $3 \mathrm{~h}$. The two-component Bacterial Viability kit (LIVE\DEAD BacLight kit, Invitrogen) was used to investigate the influence of the prooxidants on viability of rhizobial cells. Live cells were stained with Syto-9 dye, whereas dead cells with propidium iodide. 1-ml portions of cultures were centrifuged at $9,000 \times g$ for $10 \mathrm{~min}$. Obtained pellets were resuspended in $1 \mathrm{ml} 0.85 \% \mathrm{NaCl}$ and centrifugation was repeated. Then, the bacterial pellets were resuspended in $1 \mathrm{ml}$ $0.85 \% \mathrm{NaCl}$ and $50-\mu \mathrm{l}$ portions thereof were supplemented with Syto-9 and propidium iodide to the final concentrations of $5 \mu \mathrm{M}$ and $30 \mu \mathrm{M}$, respectively, and left in darkness for $20 \mathrm{~min}$ at room temperature. Subsequently, bacterial suspensions $(50-\mu \mathrm{l})$ were introduced into wells of 96-well polystyrene plates and analysed using a microscope. In order to determine the number of cells used for this analysis, a set of dilutions of the culture of $\mathrm{OD}_{600}=0.4$ was prepared for each strain, and $100-\mu 1$ portions thereof were loaded onto agar plates, incubated at $28{ }^{\circ} \mathrm{C}$ for 3 days, and the number of colonies was counted. $1 \mathrm{ml}$ of these cultures of the Rt24.2, Rt5819, and Rt2472 strains contained $8.16 \times$ $10^{8}, 8.82 \times 10^{8}$, and $8.23 \times 10^{8}$ cells, respectively. The Olympus SV1000 microscope was used for visualization of the prooxidant-treated bacterial cells. For each strain and each condition, the experiment described was repeated three times. The ratio of live to dead cells was calculated using the ImageJ $1.43 \mathrm{e}$ software (Wayne Rasband, NIH, USA).

Plant tests

Red clover (Trifolium pratense cv. Diana) seeds were surface sterilized using $0.1 \% \mathrm{HgCl}_{2}$ (3 min), three washes with sterile water, $70 \%$ ethanol (3 $\mathrm{min})$, and next three washes with water. Subsequently, the seeds were placed on Fåhraeus agar plates where they germinated. Then, seedlings were transferred onto Fåhraeus slants for further growth (Vincent 1970). Four-day-old seedlings were inoculated with bacterial suspensions of Rt24.2 and its derivatives (Rt5819 and Rt2472) of $\mathrm{OD}_{600}=0.2(100 \mu \mathrm{l}$ per plant $)$ and grown 28 days under natural light supplemented with artificial light (14-h day at $24{ }^{\circ} \mathrm{C}$ and 10 -h night at $18{ }^{\circ} \mathrm{C}$ ) in a greenhouse. To study the effect of menadione and $\mathrm{H}_{2} \mathrm{O}_{2}$ on nodulation ability of these strains and their effectiveness in symbiosis with clover, $10-\mathrm{ml}$ bacterial suspensions of $\mathrm{OD}_{600}$ of 0.2 were incubated with $1.5 \mathrm{mM} \mathrm{H}_{2} \mathrm{O}_{2}$ or $0.3 m M \mathrm{MQ}$ for $1 \mathrm{~h}$ at $28^{\circ} \mathrm{C}$. To prevent the deleterious effect of these compounds to plants, the bacteria after incubation were centrifuged $10 \mathrm{~min}$ at $5,000 \times g$, and the pellets obtained were washed twice in $5 \mathrm{ml}$ sterile water. Finally, 5-ml bacterial suspensions in water of $\mathrm{OD}_{600}=0.2$ were prepared and $100 \mu \mathrm{l}$ portions were used to infect individual clover plants. The plants were inspected for root nodule formation every week, and after 4 weeks they were harvested and wet shoot and root masses were estimated.

\section{Statistical analysis}

The results are mean \pm SD from three experiments $(n=3)$ performed in triplicate. Comparison of values between untreated and prooxidant-treated bacteria of the particular strain and between different strains in the same conditions were performed using a one-way ANOVA to find statistically significant differences. In cases where the null hypothesis (all population means are equal) was rejected at the alpha $=0.05$ level, the Tukey's HSD (Honestly Significant Difference) test was applied. Significant differences among treatments and the tested strains were considered at the level of $p$ values $<0.05$.

\section{Chemicals}

Most of the reagents and substrates were obtained from Sigma (St. Louis, USA), POCH (Poland) and Invitrogen (USA).

\section{Results}

Growth and survivability of $R$. leguminosarum bv. trifolii in response to $\mathrm{H}_{2} \mathrm{O}_{2}$ and menadione

In order to establish the sensitivity and bacterial response to $\mathrm{H}_{2} \mathrm{O}_{2}$ - and menadione-mediated oxidative stress, the growth and survival of the $R$. leguminosarum bv. trifolii wild-type and two pss $A$ and $\operatorname{ros} R$ mutant strains were monitored in the presence of various concentrations of these compounds. Two different treatments were used. In the first one, cell cultures of low density were exposed for a long period ( $96 \mathrm{~h}$ ) to different concentrations of the stressors and the growth was determined by measurement of cell turbidity. In general, hydrogen peroxide affected the growth of these bacteria 
less drastically than MQ (Fig. 1). It was observed that 1 $m M \mathrm{H}_{2} \mathrm{O}_{2}$ did not affect the bacterial growth (with the exception of the ros $R$ mutant). $1.5 m M \mathrm{H}_{2} \mathrm{O}_{2}$ moderately

\section{$\mathrm{H}_{2} \mathrm{O}_{2}$}

A

Rt24.2 (wt)
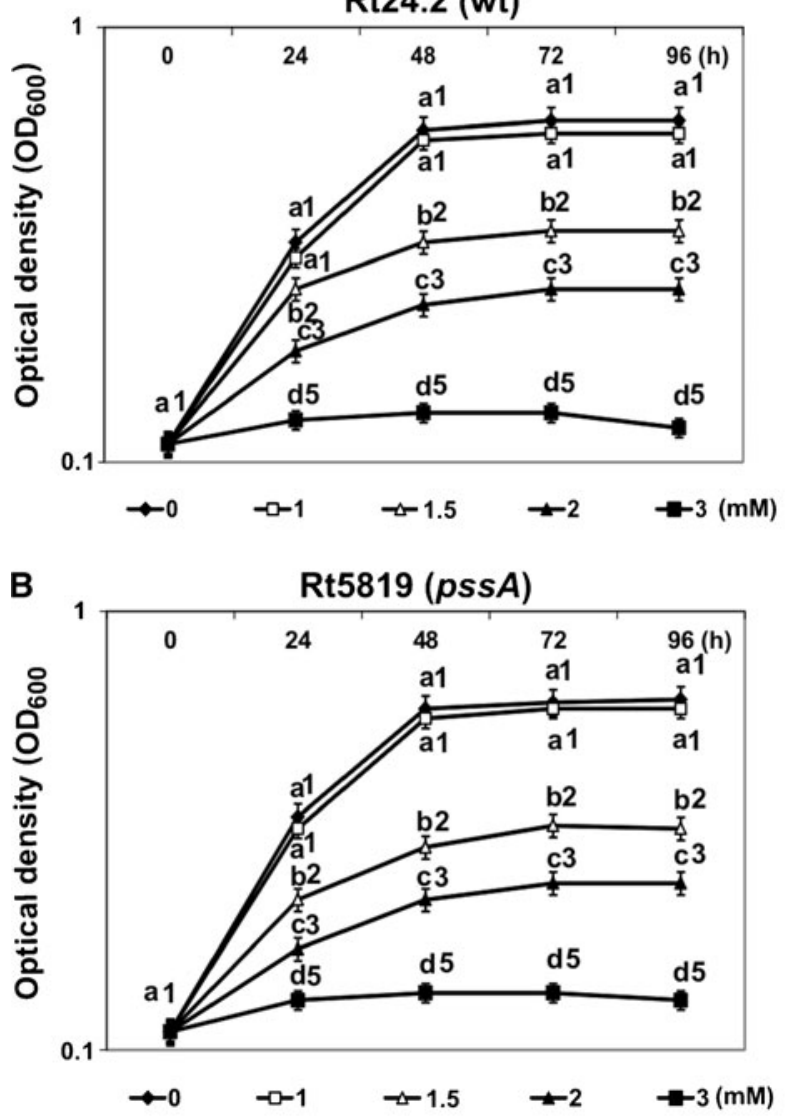

C

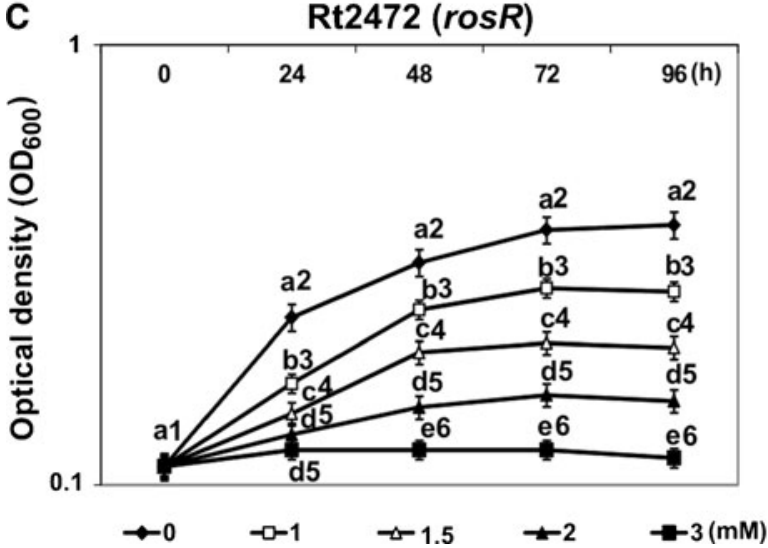

Fig. 1 The growth rate of the R. leguminosarum bv. trifolii wildtype and the pss $A$ and $\operatorname{ros} R$ mutants cultivated in TY medium supplemented with different concentrations of $\mathrm{MQ}$ and $\mathrm{H}_{2} \mathrm{O}_{2}$. Data are mean $\pm \mathrm{SD}$ for three experiments. Differences statistically decreased the growth of these strains (Fig. 1a-c), whereas the $3 \mathrm{mM}$ concentration of this prooxidant resulted in growth inhibition for all tested strains. Among these
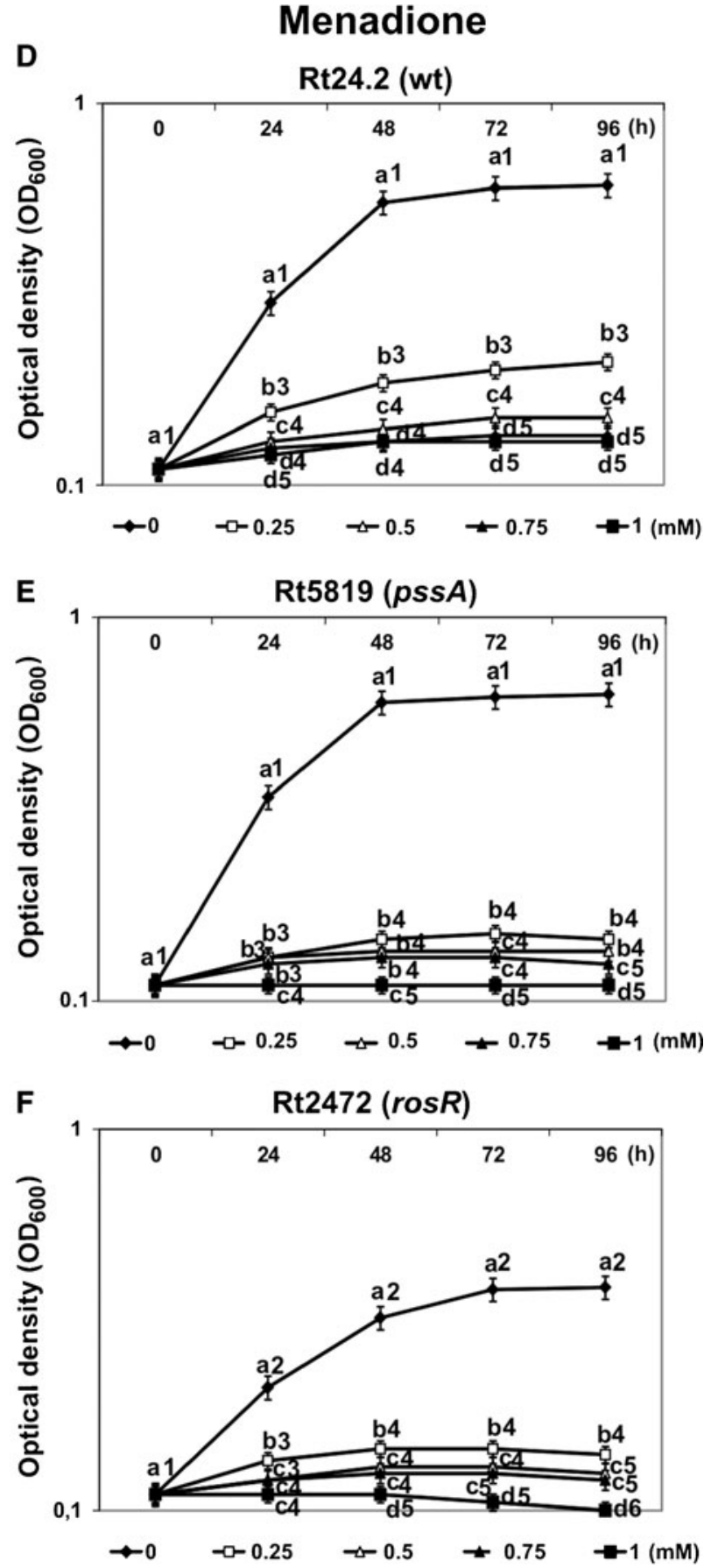

significant ( $p<0.05$; ANOVA, post hoc Tukey's test) are marked by different letters (for particular strain) and different numbers (for particular treatment) 
strains, the rosR mutant showed the highest sensitivity to hydrogen peroxide.

In contrast to $\mathrm{H}_{2} \mathrm{O}_{2}$, a strong negative effect of MQ on the growth rates of all the tested rhizobial strains was found (Fig. 1d-f). Even such a low concentration of MQ as $0.25 \mathrm{mM}$ negatively affected the bacterial growth, and $0.75 \mathrm{mM}$ of this compound resulted in total inhibition of the growth of these strains. Moreover, both pssA and rosR mutants deficient in EPS production were significantly more sensitive to this prooxidant than the wild-type strain, indicating a significant role of this polymer in protection against oxidative stress factors.

The next experiments were carried out in order to establish the highest concentration and time of treatment with the prooxidants which did not drastically affect the cell viability. To this end, different concentrations of $\mathrm{H}_{2} \mathrm{O}_{2}$ and MQ (up to $3 m M$ ) were added to 72 -h cultures of the tested strains and the incubation was continued up to $6 \mathrm{~h}$. After each $30 \mathrm{~min}$, aliquots of the cultures were taken and loaded onto agar plates, and the growth of colonies was monitored. We found that bacteria at the stationary-phase of growth were less sensitive to the oxidants in comparison to those growing in the presence of these factors. It was observed that the wild-type and both mutants survived the treatment with $0.3 \mathrm{mM} \mathrm{MQ}$ and $0.45 \mathrm{mM}$ up to $5 \mathrm{~h}$ and $3 \mathrm{~h}$, respectively.

Moreover, the bacteria retained viability after the 6-h incubation in the presence of $2 m M \mathrm{H}_{2} \mathrm{O}_{2}$. Based on

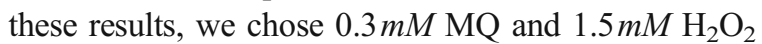
as the most appropriate for all of the tested strains for further experiments.

For more precise determination of cell viability of the R. leguminosarum bv. trifolii wild-type and the pss $A$ and ros $R$ mutants treated with these prooxidants, we calculated the ratio of live to dead cells using dyeing specific for these two types of cells (Fig. 2). The results obtained demonstrated that the mutation in $\operatorname{ros} R$ gene negatively affected cell viability of this strain (Table 1 ). In the 48-h culture of the wild-type strain, $95.1 \%$ of the bacteria were alive, whereas $85.3 \%$ of the cells were live in the case of $\operatorname{ros} R$ mutant. However, in the pss $A$ mutant, a similar level of live cells to that of the wild-type strain was observed. The treatment with $1.5 m M \mathrm{H}_{2} \mathrm{O}_{2}$ during $3 \mathrm{~h}$ did not significantly affect the viability of these strains. However, $0.3 \mathrm{mM} \mathrm{MQ}$ exerted a strong negative effect on cell viability, which was especially visible in the case of the non-mucoid pss $A$ mutant $(40.38 \%$ of live cells) (Table 1).
In summary, all these growth experiments indicate that the proper level of EPS is important for bacterial survival and adaptation to stress conditions.

The effect of EPS on survival of the rosR and pssA mutant cells in the presence of prooxidants

To study the influence of EPS on survival of the rosR and pss $A$ mutants in the presence of $\mathrm{H}_{2} \mathrm{O}_{2}$ and $\mathrm{MQ}$, 10- $\mu$ l aliquots of culture mixtures of the mutant and the wild-type strain (Rt2472/Rt24.2 and Rt5819/Rt24.2) were tested on agar plates containing different concentrations of these prooxidants $(0-3 m M)$. In addition, cultures of the wild-type and the $\operatorname{ros} R$ and $p S S A$ mutant strains were used as controls. Since both Rt5819 and Rt2472 strains are kanamycin-resistant, this antibiotic was added to the medium in order to eliminate the growth of the wild-type bacteria. After 3-day incubation, we found Rt24.2 strain colonies on plates containing $3 m M \mathrm{H}_{2} \mathrm{O}_{2}$ and $0.45 \mathrm{mM} \mathrm{MQ}$, respectively. In contrast, both $\operatorname{ros} R$ and pssA mutants showed significantly higher sensitivity to these factors and only few colonies of these bacteria were visible in the presence of $2 \mathrm{mM}$ $\mathrm{H}_{2} \mathrm{O}_{2}$ and $0.25 m M M Q$. In the case of Rt2472/Rt24.2 and Rt5819/Rt24.2 mixtures, we observed that the mutant bacteria tolerated significantly higher concentrations of the tested prooxidants $\left(3 m M \mathrm{H}_{2} \mathrm{O}_{2}\right.$ and 0.45 $m M \mathrm{MQ}$, respectively) than the mutant cells growing in the absence of EPS derived from the Rt24.2 strain (Table 2). These data confirm that EPS produced by the wild-type cells improved survival of mutant cells which are impaired in the synthesis of this extracellular polysaccharide, and the presence of EPS surrounding rhizobial cells ensures their better survival under stress conditions.

The effect of prooxidant (MQ and $\mathrm{H}_{2} \mathrm{O}_{2}$ ) treatment on CAT activity of $R$. leguminosarum bv. trifolii strains

In order to determine the response of $R$. leguminosarum bv. trifolii to $\mathrm{H}_{2} \mathrm{O}_{2}$ - and MQ-mediated oxidative stress, the levels of CAT activity and the concentrations of intracellular $\mathrm{H}_{2} \mathrm{O}_{2}$ were determined in the strains untreated and treated with these prooxidants. It was observed for the prooxidant-untreated bacteria that both pss $A$ and $\operatorname{ros} R$ mutants had more than two times higher specific CAT activity in comparison to that of the wildtype strain (Fig. 3a). Moreover, the addition of the prooxidants had a high stimulation effect in Rt24.2 

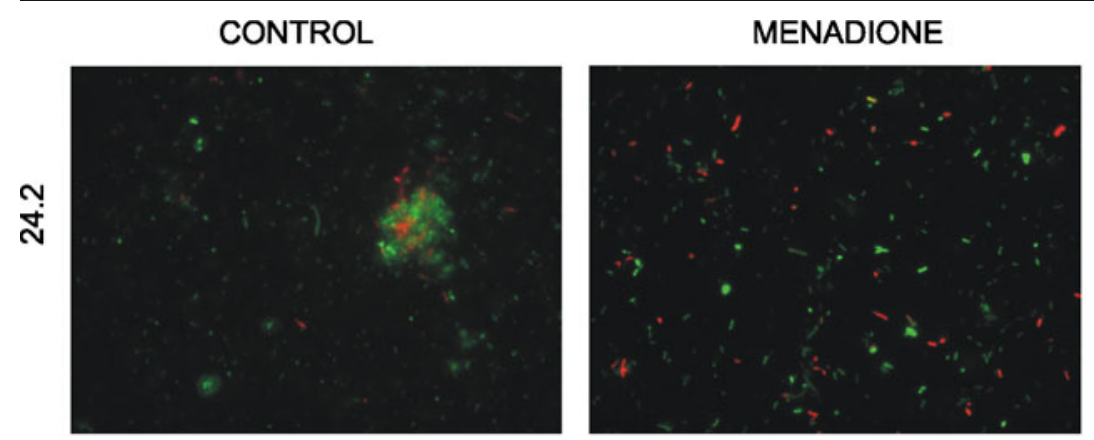

\section{HYDROGEN PEROXIDE}
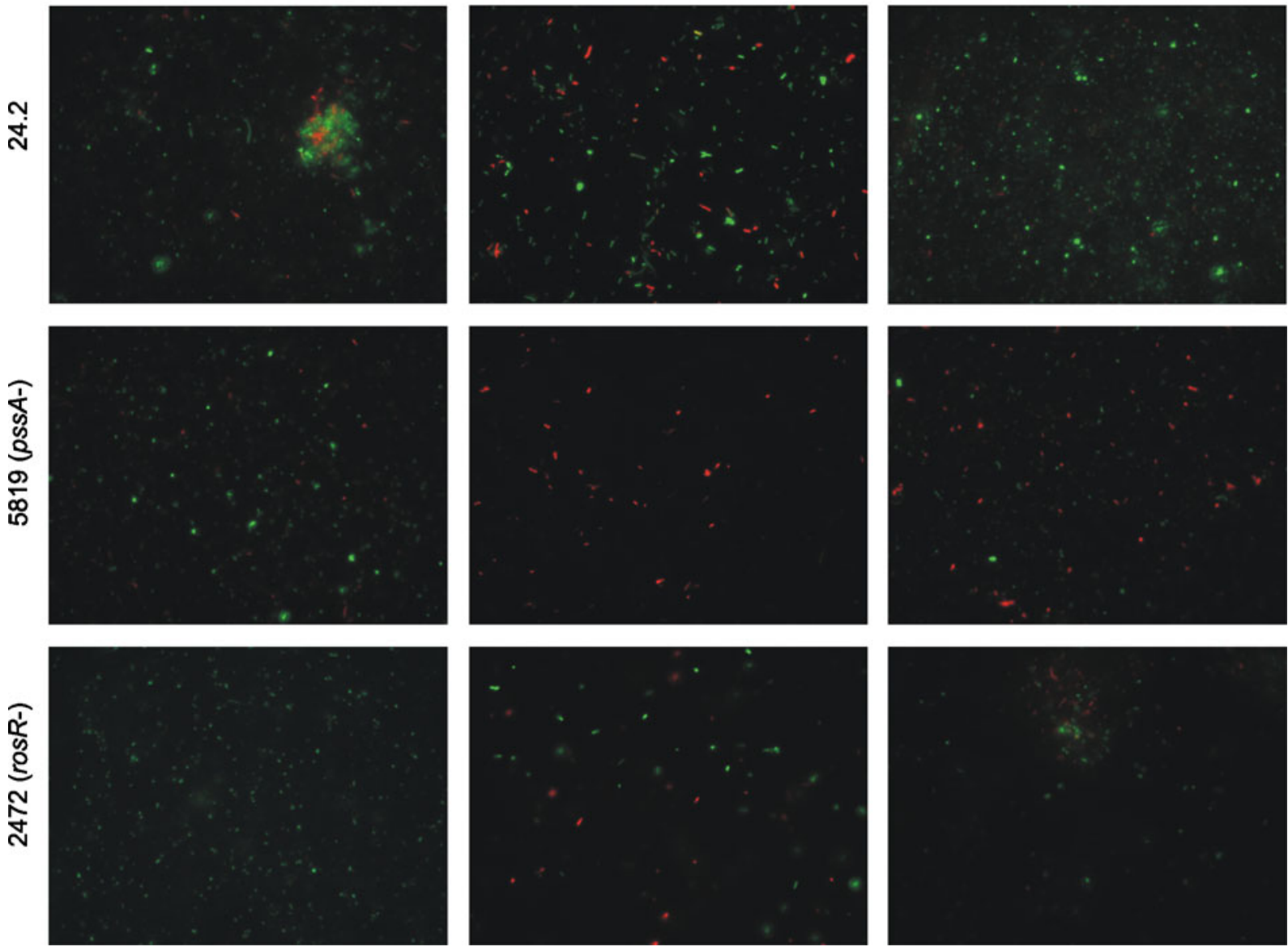

Fig. 2 Cell viability of the $R$. leguminosarum bv. trifolii wild-type and the $p s s A$ and $\operatorname{ros} R$ mutant strains treated with prooxidants (MQ and $\left.\mathrm{H}_{2} \mathrm{O}_{2}\right)(200 \times$ magnification $)$

strain. The value noted for the $\mathrm{H}_{2} \mathrm{O}_{2}$-treated bacteria was 2.5 -fold higher in relation to the control and even 4.5-fold higher in the MQ-treated cells. In the case of the pssA mutant, the presence of the prooxidants slightly decreased the level of CAT activity. For the rosR mutant, the level of CAT activity in the presence of MQ was slightly higher in relation to the strain untreated with this factor. $\mathrm{H}_{2} \mathrm{O}_{2}$ caused even higher increase in CAT activity in the ros $R$ mutant cells in comparison to MQ.

In addition, the levels of intracellular $\mathrm{H}_{2} \mathrm{O}_{2}$ in the strains untreated and treated with these stress factors

Table 1 The influence of prooxidants on cell viability of the $R$. leguminosarum bv. trifolii wild-type and the pss $A$ and ros $R$ mutant strains

Prooxidant treatment

Viability of R. leguminosarum bv. trifolii strains (\%)

\begin{tabular}{llll} 
& Rt24.2 (wild-type) & Rt5819 (pss A mutant) & Rt2472 (rosR mutant) \\
\hline Non-treated & $95.1 \pm 3.4^{\mathrm{a} 1}$ & $92.9 \pm 3.6^{\mathrm{a} 1}$ & $85.1 \pm 3.5^{\mathrm{a} 2}$ \\
$1.5 m M \mathrm{H}_{2} \mathrm{O}_{2}$ & $93.2 \pm 3.8^{\mathrm{a} 1}$ & $92.3 \pm 4.3^{\mathrm{a} 1}$ & $84.0 \pm 3.3^{\mathrm{a} 2}$ \\
$0.3 m M \mathrm{MQ}$ & $71.3 \pm 3.5^{\mathrm{b} 1}$ & $40.4 \pm 2.1^{\mathrm{b} 3}$ & $61.8 \pm 2.9^{\mathrm{b} 2}$ \\
\hline
\end{tabular}

The given values ( \pm standard deviation) are averages of three biological repeats performed in triplicate. The data within the column followed by different letters (for a particular strain) and within the rows followed by different numbers (for a particular treatment) significantly different at $p<0.05$ (ANOVA, post hoc Tukey's test) 
Table 2 The influence of exopolysaccharide on survival of the R. leguminosarum bv. trifolii pss $A$ and ros $R$ mutant strains

Bacterial culture or culture mixture The number of bacterial colonies growing in the presence of different concentrations of prooxidants

\begin{tabular}{|c|c|c|c|c|c|c|c|c|c|}
\hline & \multicolumn{5}{|c|}{ Hydrogen peroxide $(m M)$} & \multicolumn{4}{|c|}{ Menadione $(m M)$} \\
\hline & 1.0 & 1.5 & 2.0 & 2.5 & 3.0 & 0.25 & 0.45 & 0.75 & 1.0 \\
\hline Rt24.2 (wild-type) & un. & un. & $25 \pm 4^{\mathrm{A}, \mathrm{a}}$ & $11 \pm 3^{\mathrm{B}, \mathrm{b}}$ & $4 \pm 1^{\mathrm{B}, \mathrm{c}}$ & $26 \pm 5^{\mathrm{A}, \mathrm{a}}$ & $14 \pm 3^{\mathrm{B}, \mathrm{b}}$ & $0 \pm 0^{\mathrm{A}, \mathrm{d}}$ & $0 \pm 0^{\mathrm{A}, \mathrm{d}}$ \\
\hline $\operatorname{Rt5819}(p s s A)$ & un. & un. & $2 \pm 1^{\mathrm{C}, \mathrm{a}}$ & $0 \pm 0^{\mathrm{C}, \mathrm{b}}$ & $0 \pm 0^{\mathrm{C}, \mathrm{b}}$ & $3 \pm 1^{\mathrm{C}, \mathrm{a}}$ & $0 \pm 0^{\mathrm{C}, \mathrm{b}}$ & $0 \pm 0^{\mathrm{A}, \mathrm{b}}$ & $0 \pm 0^{\mathrm{A}, \mathrm{b}}$ \\
\hline Rt2472 (rosR) & un. & un. & $9 \pm 2^{\mathrm{B}, \mathrm{a}}$ & $0 \pm 0^{\mathrm{C}, \mathrm{b}}$ & $0 \pm 0^{\mathrm{C}, \mathrm{b}}$ & $8 \pm 2^{\mathrm{B}, \mathrm{a}}$ & $0 \pm 0^{\mathrm{C}, \mathrm{b}}$ & $0 \pm 0^{\mathrm{A}, \mathrm{b}}$ & $0 \pm 0^{\mathrm{A}, \mathrm{b}}$ \\
\hline Rt5819/Rt24.2 & un. & un. & $32 \pm 4^{\mathrm{A}, \mathrm{a}}$ & $20 \pm 3^{\mathrm{A}, \mathrm{a}}$ & $8 \pm 2^{\mathrm{A}, \mathrm{b}}$ & $31 \pm 5^{\mathrm{A}, \mathrm{a}}$ & $24 \pm 5^{\mathrm{A}, \mathrm{a}}$ & $0 \pm 0^{\mathrm{A}, \mathrm{c}}$ & $0 \pm 0^{\mathrm{A}, \mathrm{c}}$ \\
\hline Rt2472/Rt24.2 & un. & un. & $38 \pm 6^{\mathrm{A}, \mathrm{a}}$ & $26 \pm 6^{\mathrm{A}, \mathrm{a}}$ & $11 \pm 3^{\mathrm{A}, \mathrm{b}}$ & $36 \pm 6^{\mathrm{A}, \mathrm{a}}$ & $28 \pm 6^{\mathrm{A}, \mathrm{a}}$ & $0 \pm 0^{\mathrm{A}, \mathrm{c}}$ & $0 \pm 0^{\mathrm{A}, \mathrm{c}}$ \\
\hline
\end{tabular}

un. uncountable number of bacterial colonies visible as a monolayer spot

A, B, C Within the same column, means followed by different letters are significantly different at $p<0.05$, ANOVA, post hoc Tukey's test a,b,c,d Within the same row, means for the individual strain followed by different letters are significantly different at $p<0.05$, ANOVA, post hoc Tukey's test

were determined (Fig. 3b). In general, this analysis revealed that the concentration of $\mathrm{H}_{2} \mathrm{O}_{2}$ in cells is
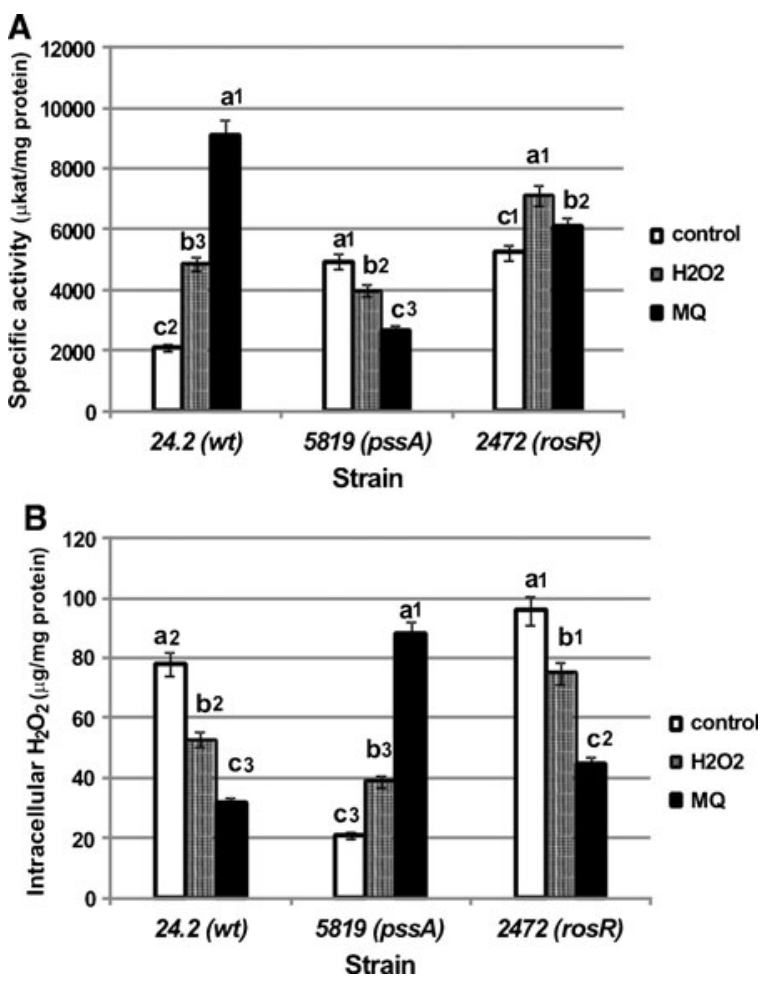

Fig. 3 Specific CAT activity (a) and intracellular level of $\mathrm{H}_{2} \mathrm{O}_{2}$ (b) assayed in bacteria of $R$. leguminosarum bv. trifolii wild-type strain and its derivatives after treatment with prooxidants. Data are mean \pm SD for three measurements. Differences statistically significant ( $p<0.05$; ANOVA, post hoc Tukey's test) are marked by different letters (for particular strain) and different numbers (for particular treatment) opposite to the level of specific CAT activity (when the individual strain and condition was compared). In the wild-type strain, the lowest CAT activity and the highest concentration of $\mathrm{H}_{2} \mathrm{O}_{2}$ were observed in the absence of the stressors, whereas the treatment of bacteria with these factors increased the levels of CAT activity and decreased the amount of $\mathrm{H}_{2} \mathrm{O}_{2}$. The rosR mutant exhibited a profile of $\mathrm{H}_{2} \mathrm{O}_{2}$ levels very similar to that of the wild-type strain, although the values were significantly higher. In contrast to these strains, the untreated bacteria of the pss $A$ mutant had the lowest concentration of $\mathrm{H}_{2} \mathrm{O}_{2}$, and higher levels of $\mathrm{H}_{2} \mathrm{O}_{2}$ in the presence of the prooxidants.

Moreover, the detection of CAT activity on native PAGE gels was performed, which revealed the presence of two or three bands exhibiting enzyme activity (Fig. 4). In the case of the rosR mutant, bands with stronger intensity of CAT activity in the control as well as in the prooxidant-treated samples were observed. Moreover, an additional band of CAT activity was detected in this mutant treated with $\mathrm{H}_{2} \mathrm{O}_{2}$.

The effect of MQ and $\mathrm{H}_{2} \mathrm{O}_{2}$ treatment on SOD activity

Our previous studies indicated that mutations in $\operatorname{ros} R$ and pss $A$ genes resulted in several pleiotropic effects, among them disturbances in membrane integrity causing unspecific protein leakage (Janczarek et al. 2009a, 2010). Therefore, the levels of both extracellular and intracellular SOD activity have been determined. We have found that the specific activity of SOD in the supernatant obtained from the Rt24.2 culture reached a 
Fig. 4 Native PAGE electrophoresis of intracellular CAT activity in the $R$.

leguminosarum bv. trifoli

wild-type and pss $A$ and $\operatorname{ros} R$ mutants treated with prooxidants (MQ and $\mathrm{H}_{2} \mathrm{O}_{2}$ ). $15 \mu \mathrm{g}$ of proteins were introduced into each well of $12.5 \%$ native polyacrylamide gel

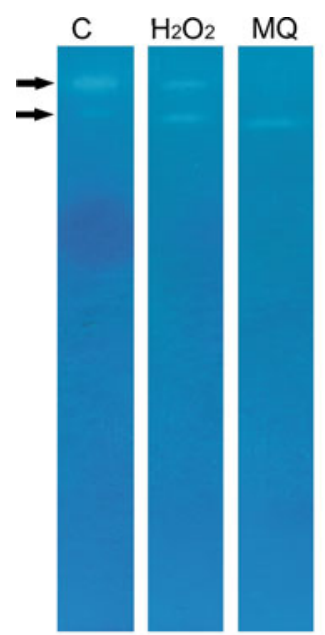

24.2 (wt)

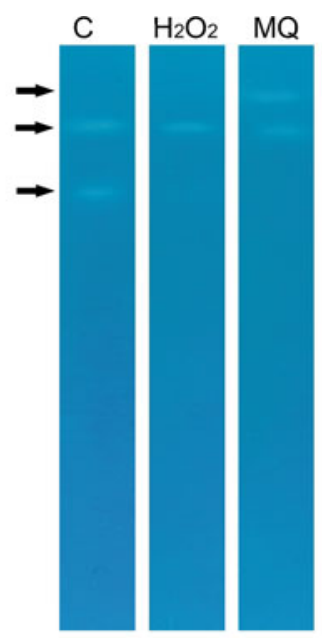

5819 (pssA)

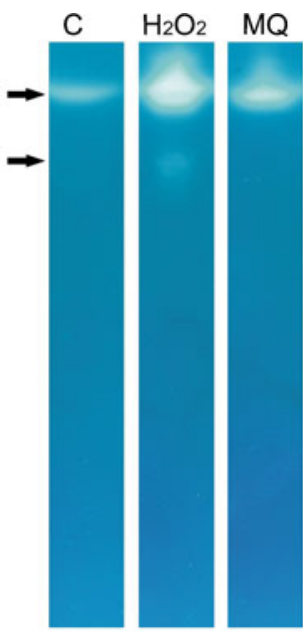

2472 (rosR) very low level (below $1 \mathrm{U}$ per mg of extracellular protein) (Fig. 5a). The presence of the stress factors (especially MQ) in the cultures of this strain enhanced extracellular SOD activity in comparison to the control.

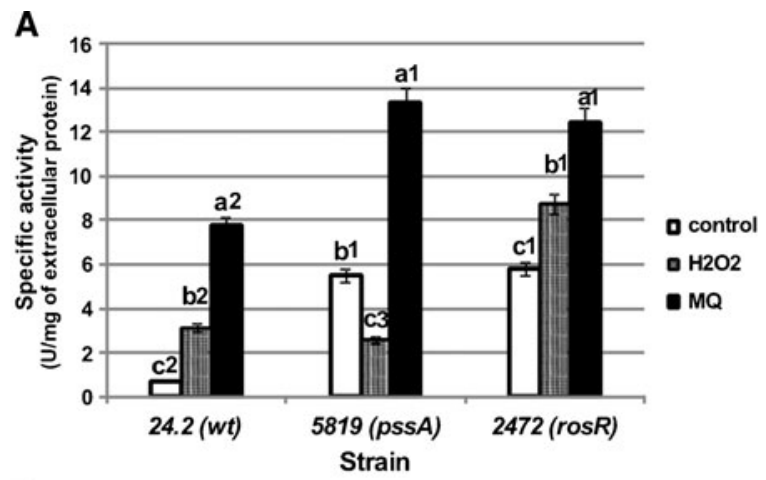

B

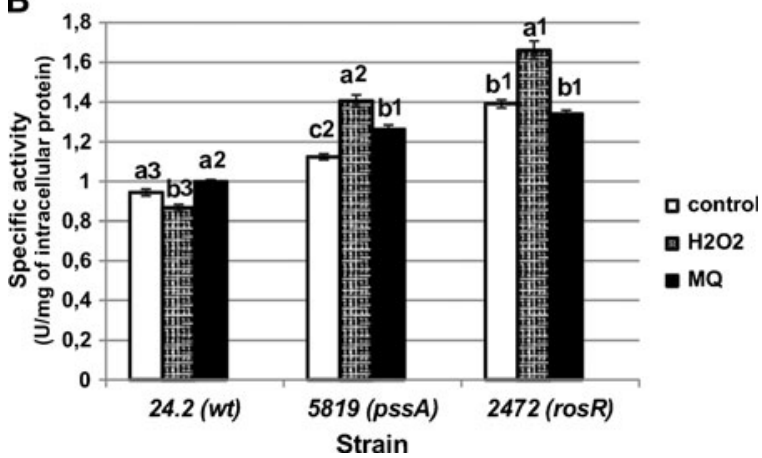

Fig. 5 The effect of prooxidants on extracellular (a) and intracellular (b) specific SOD activity in the wild-type R. leguminosarum bv. trifolii and the $p s s A$ and $\operatorname{ros} R$ mutants. Data are mean \pm SD for three measurements. Differences statistically significant $(p<0.05$; ANOVA, post hoc Tukey's test) are marked by different letters (for particular strain) and different numbers (for particular treatment)
The supernatants of both pss $A$ and $\operatorname{ros} R$ mutants untreated with prooxidants demonstrated significantly higher SOD activity in comparison to the Rt24.2. In addition, the presence of the stressors in the cultures of these mutants resulted in a significant increase in extracellular SOD activity, with the exception of the pssA mutant treated with $\mathrm{H}_{2} \mathrm{O}_{2}$. The most important changes appeared in the case of this strain treated with MQ ( $\sim 13.5 \mathrm{U}$ per mg of protein). Furthermore, the addition of $\mathrm{H}_{2} \mathrm{O}_{2}$ stimulated the SOD activity in the Rt24.2 and even higher in the ros $R$ mutant. These results show that the mutations in both pss $A$ and $\operatorname{ros} R$ genes result in remarkably higher activities of SOD in control cultures in relation to the wild-type and in most cases the stress factors additionally increase the level of this activity (Fig. 5a).

The intracellular specific activity of SOD in the Rt24.2 was similar to that established in the supernatant of this strain. However, the addition of the prooxidants did not significantly affect the level of this activity within the wild-type bacteria (Fig. 5b). Both the Rt5819 and Rt2472 mutants displayed a moderate increase in the intracellular SOD activity in comparison to the wild-type strain. Moreover, the presence of $1.5 \mathrm{mM}$ of $\mathrm{H}_{2} \mathrm{O}_{2}$ resulted in a significant increase in the specific SOD activity in these mutants. The highest activity was detected in the case of the $\mathrm{H}_{2} \mathrm{O}_{2}$-treated rosR mutant $(\sim 1.65 \mathrm{U}$ per $\mathrm{mg}$ of protein). The SOD activities analysed in native electrophoresis showed the presence of one or two bands exhibiting the activity of this enzyme in all of the tested strains both in the control samples and after induction by $\mathrm{H}_{2} \mathrm{O}_{2}$ and MQ (Fig. 6). The intensity of SOD bands in the strains treated with 
Fig. 6 Native PAGE electrophoresis of intracellular SOD activity in the pss $A$ and $\operatorname{ros} R$ mutants and the wild-type $R$. leguminosarum bv. trifoli bacteria treated with hydrogen peroxide and menadione (15 $\mu \mathrm{g}$ of proteins were introduced into each well of $12.5 \%$ native polyacrylamide gel)

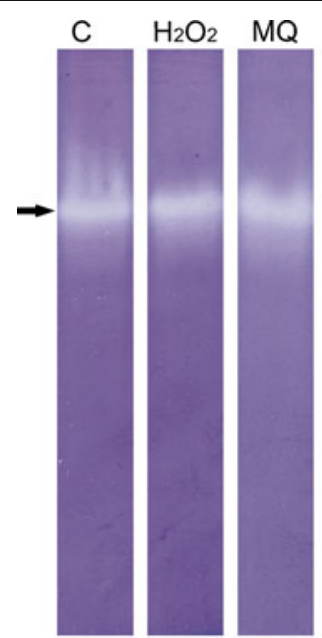

24.2 (wt)

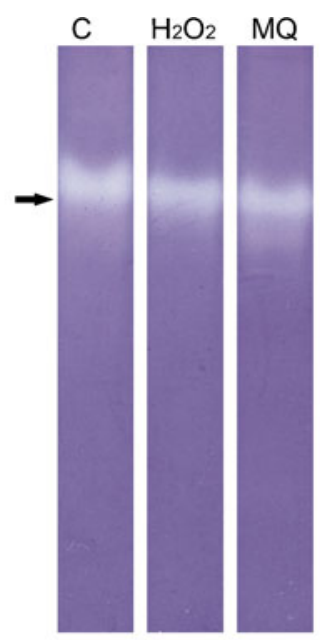

5819 (pssA)

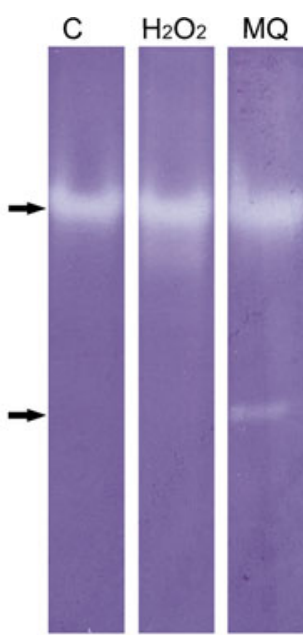

2472 (rosR) the prooxidants seemed stronger than in the control. Interestingly, an additional band of SOD activity was detected in the MQ-treated cells of the rosR mutant.

The influence of prooxidants on the levels of SOR, FA, and PHC

The levels of some low-molecular-weight compounds (SOR, FA, and PHC) connected with cellular stress response were estimated in the rhizobial strains. The data were compared to those obtained for the control of the wild-type strain Rt24.2 (100\%) and presented in Table 3 as a percentage of their values. In general, the extracellular and intracellular levels of these compounds significantly differed between the Rt24.2 and both Rt5819 (pssA) and Rt2472 (rosR) mutants. In the wildtype strain, $\mathrm{H}_{2} \mathrm{O}_{2}$ caused an increase in both the intracellular and extracellular levels of formaldehyde (FA) and extracellular phenolic compounds (PHC), whereas MQ resulted in higher amounts of intra- and extracellular superoxide anion radicals (SOR) (Table 3). The pss A mutant displayed a 2.5-fold lower level of extracellular $\mathrm{PHC}$ than the wild-type. Moreover, the addition of $\mathrm{H}_{2} \mathrm{O}_{2}$ to the culture of this strain resulted in an increase in all of the assayed extra- and intracellular compounds, with the exception of the intracellular PHC. Additionally, MQ present in the cultures increased the amounts of extracellular SOR and FA. However, the highest differences in the levels of these compounds were found in the case of the Rt2472 strain (Table 3). Cells of this mutant showed a higher level of intracellular FA (140\% of the value for Rt24.2) and a very low level of PHC (39.36 \%). Moreover, significantly increased amounts of SOR (153\%), FA (225\%), and PHC (171\%) were found in the culture supernatant of this mutant in comparison to the wild-type, and both prooxidants additionally affected the levels of these compounds.

The effect of MQ and $\mathrm{H}_{2} \mathrm{O}_{2}$ on the activity of pectinase and $\beta$-glucosidase

Biochemical studies concerning extracellular pectinaselike activity in cultures of the wild-type $R$. leguminosarum bv. trifolii and the pss $A$ and rosR mutants showed significant differences between these strains. A nearly 2 -fold lower pectinolytic activity was found in the supernatant of the pss $A$ mutant in relation to the Rt24.2 (Fig. 7a). On the other hand, a 2-fold higher activity was evidenced in the supernatant of the rosR mutant compared to that in the parental strain. In addition, it was observed that both $\mathrm{H}_{2} \mathrm{O}_{2}$ and MQ caused an increase in the pectinolytic activity in the Rt24.2 and the Rt5819 strains. The most visible stimulation effect was observed in the cultures treated with $0.3 \mathrm{mM} \mathrm{MQ}$, reaching an approximate value of $\sim 54 \mathrm{U}$ and $\sim 40 \mathrm{U}$ per $\mathrm{mg}$ of protein for the wild-type and the pss $A$ mutant, respectively. In contrast, the Rt2472 mutant displayed a distinct profile of this enzymatic activity in comparison to the remaining strains. The highest pectinolytic activity was detected in the culture of this mutant with no added prooxidants. In the presence of $\mathrm{H}_{2} \mathrm{O}_{2}$ and $\mathrm{MQ}$, lower levels of this enzymatic activity were established, suggesting no stimulation effect of these factors on the rosR mutant.

The studies concerning the activity of extracellular $\beta$ glucosidase $(\beta-G L U)$ revealed a similar enzymatic 
Table 3 The influence of prooxidants on the levels of intracellular and extracellular superoxide anion radicals (SOR), formaldehyde (FA) and phenolic compounds (PHC) determined in the R. leguminosarum bv. trifolii wild-type and the pss $A$ and rosR mutants

\begin{tabular}{|c|c|c|c|c|c|c|}
\hline \multirow[t]{2}{*}{ Strains } & \multicolumn{3}{|c|}{ Intracellular level ${ }^{*}$} & \multicolumn{3}{|c|}{ Extracellular level $^{*}$} \\
\hline & SOR (\%) & FA $(\%)$ & PHC (\%) & SOR (\%) & FA $(\%)$ & PHC (\%) \\
\hline Rt24.2 & $100 \pm 6.2^{\mathrm{b} 1}$ & $100 \pm 2.7^{\mathrm{b} 3}$ & $100 \pm 7.5^{\mathrm{a} 1}$ & $100 \pm 11.6^{\mathrm{b} 2}$ & $100 \pm 5.6^{\mathrm{c} 2}$ & $100 \pm 4.0^{\mathrm{b} 2}$ \\
\hline $\mathrm{Rt} 24.2 \mathrm{H}_{2} \mathrm{O}_{2}$ & $105.6 \pm 2.4^{\mathrm{b} 2}$ & $122.3 \pm 2.5^{\mathrm{ac} 3}$ & $74.8 \pm 2.9^{\mathrm{b} 2}$ & $98.9 \pm 3.8^{\mathrm{b} 3}$ & $148.5 \pm 14.4^{\mathrm{a} 1}$ & $133.59 \pm 2.1^{\mathrm{a} 2}$ \\
\hline Rt24.2 MQ & $138.9 \pm 6.0^{\mathrm{a} 1}$ & $111.8 \pm 5.9^{\mathrm{bc} 1}$ & $51.6 \pm 2.7^{\mathrm{c} 2}$ & $145.5 \pm 5.6^{\mathrm{a} 3}$ & $114.1 \pm 3.4^{\mathrm{b} 2}$ & $84.45 \pm 1.4^{\mathrm{c} 2}$ \\
\hline Rt5819 & $116.7 \pm 7.6^{\mathrm{b} 1}$ & $119.3 \pm 11.4^{\mathrm{b} 2}$ & $98.4 \pm 3.4^{\mathrm{a} 1}$ & $110.3 \pm 3.5^{\mathrm{c} 2}$ & $103.9 \pm 1.3^{\mathrm{c} 2}$ & $40.60 \pm 0.1^{\mathrm{c} 3}$ \\
\hline $\mathrm{Rt} 5819 \mathrm{H}_{2} \mathrm{O}_{2}$ & $138.0 \pm 4.4^{\mathrm{a} 1}$ & $199.3 \pm 0.6^{\mathrm{a} 1}$ & $97.8 \pm 8.6^{\mathrm{a} 1}$ & $173.9 \pm 9.7^{\mathrm{b} 1}$ & $123.7 \pm 12.9^{\mathrm{b} 1,2}$ & $144.49 \pm 3.4^{\mathrm{a} 1}$ \\
\hline Rt5819 MQ & $111.1 \pm 2.9^{\mathrm{b} 2}$ & $106.6 \pm 10.4^{\mathrm{b} 1}$ & $51.9 \pm 4.1^{\mathrm{b} 2}$ & $211.8 \pm 5.8^{\mathrm{a} 1}$ & $148.3 \pm 5.5^{\mathrm{a} 1}$ & $87.74 \pm 1.2^{\mathrm{b} 2}$ \\
\hline Rt2472 & $94.4 \pm 4.0^{\mathrm{a} 1}$ & $141.0 \pm 13.3^{\mathrm{a} 1}$ & $39.4 \pm 2.3^{\mathrm{b} 2}$ & $153.8 \pm 0.8^{\mathrm{a} 1}$ & $225.9 \pm 14.0^{\mathrm{a} 1}$ & $171.1 \pm 1.6^{\mathrm{a} 1}$ \\
\hline $\mathrm{Rt} 2472 \mathrm{H}_{2} \mathrm{O}_{2}$ & $72.2 \pm 8.4^{\mathrm{b} 3}$ & $156.7 \pm 5.1^{\mathrm{a} 2}$ & $73.0 \pm 5.4^{\mathrm{a} 2}$ & $149.6 \pm 4.2^{\mathrm{bc} 2}$ & $125.8 \pm 5.5^{\mathrm{b} 2}$ & $66.0 \pm 0.3^{\mathrm{c} 3}$ \\
\hline Rt2472 MQ & $66.7 \pm 4.7^{\mathrm{b} 3}$ & $110.5 \pm 3.1^{\mathrm{b} 1}$ & $84.7 \pm 7.0^{\mathrm{a} 1}$ & $156.5 \pm 1.5^{\mathrm{ac} 2}$ & $114.8 \pm 1.1^{\mathrm{c} 2}$ & $104.7 \pm 1.1^{\mathrm{b} 1}$ \\
\hline
\end{tabular}

* Relative levels of superoxide anion radicals (SOR), formaldehyde (FA) and phenolic compounds are given in \% of the control values of the Rt24.2 strain. The given values ( \pm standard deviation) are averages of three independent experiments performed in triplicate

a,b,c Different letters indicate significantly different values for a particular SOR assayed in the individual strain untreated and treated with MQ and $\mathrm{H}_{2} \mathrm{O}_{2}$ (data within the column compared) ( $p \leq 0.05$; ANOVA, post hoc Tukey's test)

${ }^{1,2,3}$ Different numbers indicate significantly different values for individual SOR assayed in Rt24.2, Rt5819 and Rt2472 strains in particular conditions (untreated strains; the strains treated with MQ; and the strains treated with $\left.\mathrm{H}_{2} \mathrm{O}_{2}\right)(p \leq 0.05$; ANOVA, post hoc Tukey's test)

profile for both the wild-type and the pssA mutant (Fig. 7b). A very low level of the $\beta$-GLU activity in the culture supernatants of these strains was observed. The presence of $1.5 \mathrm{mM} \mathrm{H}_{2} \mathrm{O}_{2}$ and $0.3 \mathrm{mM} \mathrm{MQ}$ resulted in a higher enzymatic activity, and a significant increase (4-fold for the Rt24.2 and nearly 6-fold for the Rt5818) was observed after addition of MQ to the bacterial cultures. In contrast, the ros $R$ mutant displayed a different enzymatic profile in relation to these strains. In the culture supernatant of Rt2472, a 3.5-fold higher $\beta$-GLU activity in comparison to that of the wild-type and the pssA mutant was observed. The addition of $\mathrm{H}_{2} \mathrm{O}_{2}$ did not significantly change the level of this activity in the Rt2472 supernatant. Moreover, MQ only slightly increased the level of extracellular $\beta$-GLU activity.

The influence of prooxidants on symbiosis of $R$. leguminosarum bv. trifolii strains with clover

The wild-type strain and the pssA and rosR mutants were used to study the effect of menadione and $\mathrm{H}_{2} \mathrm{O}_{2}$ on symbiosis of $R$. leguminosarum bv. trifolii with clover. In this experiment, before infection of clover plants these strains were incubated for $1 \mathrm{~h}$ at $28^{\circ} \mathrm{C}$ in the presence of $1.5 m M \mathrm{H}_{2} \mathrm{O}_{2}$ and $0.3 m M \mathrm{MQ}$. Control plants were infected by bacteria that were not treated by these stress factors. We have observed that both tested stressors affected the nodulation ability and, in consequence, efficiency in nitrogen fixation of the wild-type strain (Table 4). MQ exerted a stronger negative effect than $\mathrm{H}_{2} \mathrm{O}_{2}$ on the symbiotic properties of this strain. This was especially visible during the first week of the experiment, when MQ caused a significant reduction (to $40 \%$ ) of nodules induced by these bacteria on clover roots. The $p s s A$ and $\operatorname{ros} R$ mutants are strongly impaired in symbiosis. All nodules induced on clover plants by the pss $A$ mutant are small, white, and non-functional. In addition, the $\operatorname{ros} R$ mutant elicits formation of nodules with significantly less effectiveness than those induced by the wild-type strain. In the case of these mutants, prooxidant-treated bacteria induced a decreased number of nodules than untreated cells. The shoot mass of host plants reflects the efficiency of the nitrogen-fixation process. The shoot weight in the plants infected by $\mathrm{H}_{2} \mathrm{O}_{2}$-treated $\mathrm{Rt} 24.2$ was significantly lower than in those infected by untreated bacteria. Moreover, MQ had even a stronger effect on this symbiotic property of the Rt24.2, resulting in a decrease in the plant shoot mass to $54.3 \%$ of the control. For both the Rt5819 and Rt2472 mutants, the further reduction of the plant shoot mass in the presence of the prooxidants was very low, since the shoot masses of plants infected by these mutants untreated with the stressors were only moderately higher than those of uninfected plants. 


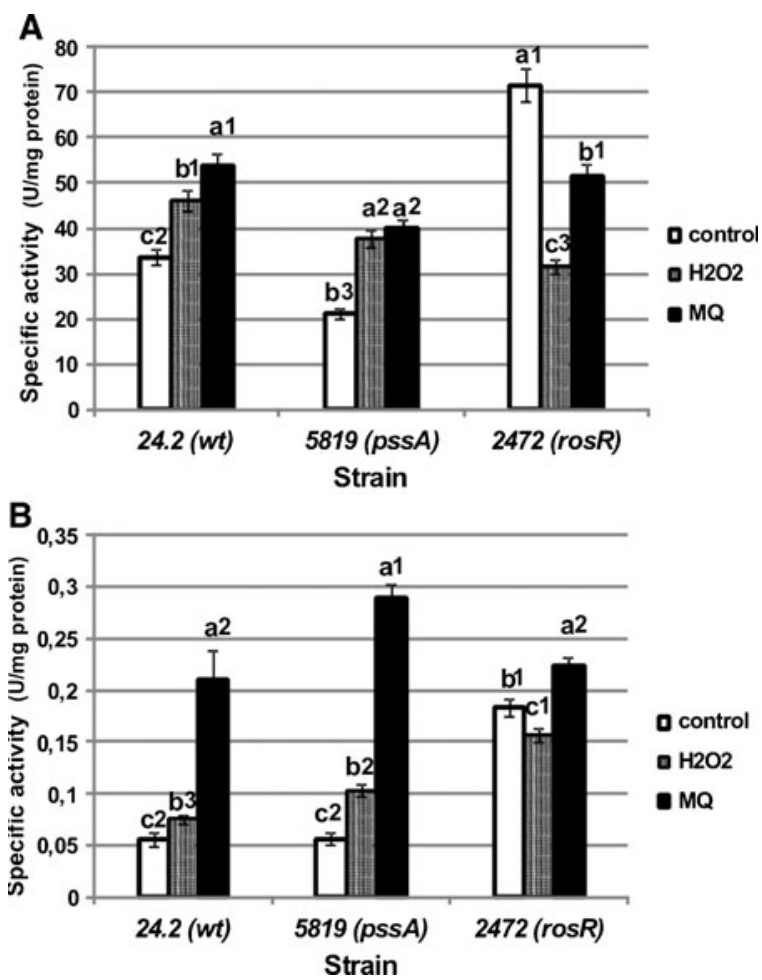

Fig. 7 The effect of prooxidants on extracellular PEC (a) and $\beta$ GLU (b) specific activity in the R. leguminosarum bv. trifolii wildtype and pss $A$ and $\operatorname{ros} R$ mutants. Data are mean $\pm \mathrm{SD}$ for three measurements. Differences statistically significant $(p<0.05$; ANOVA, post hoc Tukey's test) are marked by different letters (for particular strain) and different numbers (for particular treatment)

In summary, our data indicate that both stress factors affect the first step of symbiosis (induction of nodule formation on the host roots), that, in consequence, leads to a decrease in symbiotic efficiency.

\section{Discussion}

The oxidative stress phenomenon, i.e. the subject of the present work, very often appears to be a consequence of reactions triggered by prooxidative targets such as menadione, paraquat, metal ions and others, when the levels of produced ROS increase beyond the antioxidant capacity of cells (Jamieson 1998; Corticeiro et al. 2006). Since the physiological life cycle of rhizobia during the legume-rhizobia symbiosis is strictly correlated with the relatively high concentration of reactive oxygen intermediates such as SOR, hydroxyl radicals, and hydrogen peroxide, it is evidenced that these organisms must evolve efficient anti-stress mechanisms (Hérouart et al. 2002; Saenkham et al. 2007).

The classic bacterial ROS defence arsenal comprises a complex of enzymatic and non-enzymatic antioxidants. Bacteria are able to respond directly to the increased level of ROS by enhancing the expression of ROS decaying enzymes (catalases, superoxide dismutases and peroxidases) (Dombrecht et al. 2005).

The generation and accumulation of several ROS is a first plant defence reaction that blocks pathogen attack, but Jamet et al. (2007) confirmed that a suitable amount of $\mathrm{H}_{2} \mathrm{O}_{2}$ is required for establishment of the effective Medicago sativa - S. meliloti symbiosis. An increase in the concentration of free oxygen radical derivatives was also indicated during initial stages of $R$. leguminosarum bv. trifolii symbiosis with clover (Kopcińska 2009).

We observed several differences in enzymatic activity patterns of the $R$. leguminosarum bv. trifolii wildtype strain and two pss $A$ and rosR mutants in relation to oxidative stress response. Although the antioxidative mechanisms in other groups of organisms have been often described, the profile of responses to oxidative stress is still poorly understood in rhizobia. The study reported here is probably the first attempt to demonstrate the response of $R$. leguminosarum bv. trifolii to chemically caused oxidative stress and a role of EPS in this process based on the comparison of defence parameters between the wild-type and the pss $A$ and $\operatorname{ros} R$ mutants. The genetically modified bacterial strains used in this work had been well characterized in an earlier report with respect to EPS synthesis, symbiotic properties, and response to osmotic stress (Janczarek et al. 2009a; 2010).

The implementation of the experimental program presented in this study has provided interesting data that can be analysed in two ways: estimation whether the changes in chosen biochemical parameters depend on the genetic modification of rhizobial strains and investigation of the response of these bacteria to the presence of prooxidants. The comparison of CAT, SOD, PEC, and $\beta$-GLU activities noted in the control variants (without addition of prooxidants) of the wild-type and the pss $A$ and $\operatorname{ros} R$ mutants showed that the values of specific CAT and extra- and intracellular SOD activities were significantly higher in the mutants than in the wild-type strain. In the case of PEC and $\beta$-GLU activity, only the $\operatorname{ros} R$ mutant displayed a higher activity in comparison to the wild-type. These data suggest 


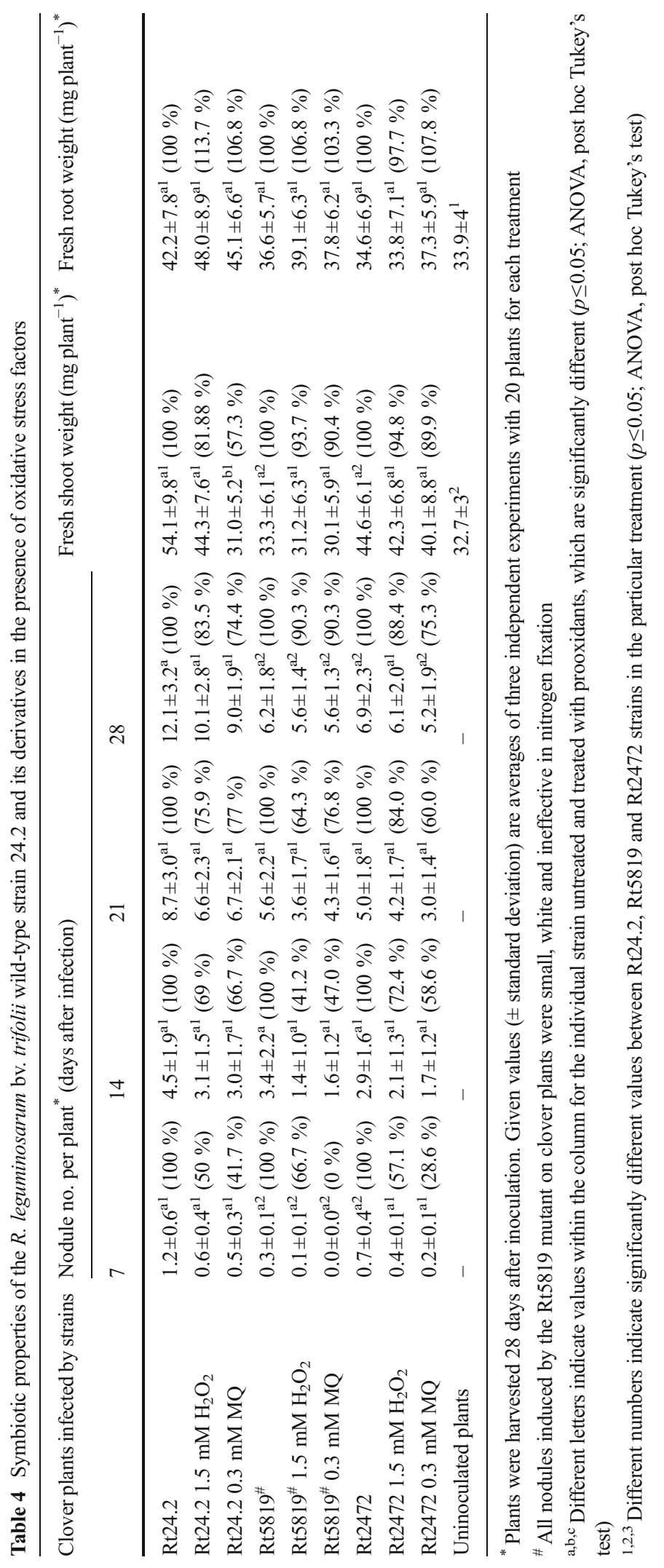


rebuilding of the metabolism of the mutants (e.g. an increase or decrease in some biochemical parameters) and a significant role of EPS in adaptation of rhizobia to stress conditions.

The wild-type bacteria were more resistant to the presence of prooxidants than the rosR and pss $A$ mutants (Figs. 1 and 2). The addition of prooxidants to the culture of the investigated strains resulted in an increase of the ROS level: SOR (the product of menadione redox cycles) and $\mathrm{H}_{2} \mathrm{O}_{2}$. The results show that the presence of MQ increased the relative level of extracellular SOR in comparison to the cultures of the non-treated wild-type strain (Table 3). The overproduction of SOR in the supernatants was strictly connected with high extracellular SOD activities (Fig. 5a). The presented data show that the mutation in both pss $A$ and $\operatorname{ros} R$ genes significantly change the level of extra- and intracellular dismutase activity in the controls as well as in the stressed bacterial cultures. A high activity of SOD was noted in the pss $A$ and $\operatorname{ros} R$ mutants and this observation was correlated with the high SOR level in these bacteria. The suitable level of SOD activities in rhizobial cells is necessary for their symbiotic properties. It was detected that the SOD-deficient mutants of $S$. meliloti did not reach the appropriate differentiation into nitrogen-fixing bacteroids (Santos et al. 2000). SOD catalyses the dismutation of SOR to hydrogen peroxide and oxygen (McCormick et al. 1998). In S. meliloti, a single superoxide dismutase was found in free-living growth conditions (Santos et al. 1999). In contrast, Agrobacterium tumefaciens possesses three SOD enzymes, among them one periplasmic and two cytoplasmic isozymes (Saenkham et al. 2007). A mutant lacking all three SODs is very sensitive to menadione treatment. In the cells of $R$. leguminosarum bv. trifolii wild-type and the pss $A$ and rosR mutants untreated and treated with the MQ and $\mathrm{H}_{2} \mathrm{O}_{2}$, we detected a single band corresponding to the SOD activity (Fig. 6). Moreover, an additional band was observed for the MQ-treated rosR mutant. Our data are in agreement with those described recently by Krehenbrink and co-workers (2011), who demonstrated that only one superoxide dismutase SodA was expressed at the stationary phase in $R$. leguminosarum bv. viciae 3841 . This protein was detected in the periplasm, although it did not have a signal peptide. Bioinformatic analysis of genomic sequences of several $R$. leguminosarum strains revealed that bacteria from this species possess two distinct genes encoding SOD proteins. These two SOD proteins are probably induced in MQ-treated cells of the ros $R$ mutant.
For detoxification of $\mathrm{H}_{2} \mathrm{O}_{2}$, bacterial cells have evolved a specific mechanism based on catalase activity (Pauly et al. 2006). $\mathrm{H}_{2} \mathrm{O}_{2}$ is a signal molecule involved in plant response to pathogen attack and other stress conditions as well as nodulation (Rubio et al. 2004). It is also known that the proper level of $\mathrm{H}_{2} \mathrm{O}_{2}$ is required for optimal establishment of symbiosis. This confirms a phenotype of $S$. meliloti bacteria overexpressing the katB gene for catalase. The higher amount of catalase significantly decreased the level of $\mathrm{H}_{2} \mathrm{O}_{2}$ in comparison to the wild-type strain and induced formation of a lower number of nodules on M. sativa roots (Jamet et al. 2007). Our data indicated about a 2.5 -fold higher CAT activity in both the pSSA and rosR mutants in relation to the wildtype (Fig. 3a). The addition of the prooxidants increased the activity of CAT in the wild-type strain and in the ros $R$ mutant, whereas this dependence was not observed in the pss $A$ mutant. Moreover, cells of the wild-type and the rosR mutant treated with these prooxidants had significantly lower levels of intracellular $\mathrm{H}_{2} \mathrm{O}_{2}$ than the nontreated bacteria (Fig. 3b). The above results suggest that one of the consequences of metabolic changes caused by these mutations in $R$. leguminosarum bv. trifolii is a higher activity of the antioxidative SOD an CAT enzymes. In silico sequence analysis performed by us indicated that $R$. leguminosarum strains usually contain one housekeeping chromosomal gene and one to two genes located on plasmids that encode catalases. Jamet et al. (2003, 2005) have indicated that S. meliloti possesses three distinct catalases: two monofunctional KatA and KatC enzymes and one bifunctional catalase-peroxydase $\mathrm{KatB}$. The $k a t B$ gene is constitutively expressed during bacterial growth in the culture and is not expressed under oxidative stress conditions, whereas the expression of the katA and katC genes was induced in these conditions. A katB katC double mutant displays abnormal infection of $M$. sativa plants and elicits essentially fewer nodules than the wild-type (Jamet et al. 2003). We have detected two to three bands indicating the CAT activity in all of the tested $R$. leguminosarum bv. trifolii strains, both untreated and treated with the MQ and $\mathrm{H}_{2} \mathrm{O}_{2}$ (Fig. 4). The highest CAT activity was observed in the rosR mutant cells both untreated and treated with the prooxidants, suggesting the possibility of biotechnological application of this strain in several bioremediation processes (Nakayama et al. 2008). Moreover, the activity of an additional CAT in the $\mathrm{H}_{2} \mathrm{O}_{2}$-induced cells of this strain has been detected. These data suggest the presence of the three CAT enzymes in R. leguminosarum bv. trifolii, 
similarly as it was evidenced in $S$. meliloti, where three catalases were differently expressed under specific environmental conditions (Jamet et al. 2003). Yuan et al. (2005) have reported that phosphate limitation induced expression of the major $\mathrm{H}_{2} \mathrm{O}_{2}$-inducible catalase gene (katA) in this organism.

Based on the enzymatic assays, we detected significantly higher catalase activity in the $R$. leguminosarum bv. trifolii wild-type strain treated with $\mathrm{H}_{2} \mathrm{O}_{2}$ and especially with $\mathrm{MQ}$ in comparison to the untreated bacteria of this strain (Fig. 3a). However, these results did not correlate with the intensity of the CAT activity obtained using native gel detection (Fig. 4). Also for the Rt2472 mutant, differences in the CAT activity for these two techniques were found. This phenomenon is difficult to explain clearly, but similar differences between native gel detection and spectrophotometric measurement of the CAT activity were presented in several reports concerning various organisms such as Saccharomyces, Neurospora crassa, Aspergillus nidulans, and maize (Gamero-Sandemetrio et al. 2013; Schliebs et al. 2006; Wadsworth and Scandalios 1990; Kawasaki and Aguirre 2001). Moreover, Gamero-Sandemetrio et al. (2013) observed similar discrepancy between zymogram and enzymatic assays for SOD activity in several $S$. cerevisiae strains, indicating that native gel detection cannot always be considered as a reliable quantitative technique.

Also, we have observed that pre-incubation of $R$. leguminosarum bv. trifolii strains with the prooxidants (especially with the MQ) negatively affected the number of nodules elicited on clover plants. This effect was the most intensively visible during the first 14 days of the experiment (Table 4). In addition, these stress factors influenced the mass of shoot plants. Previously, it was observed that the pss $A$ mutant totally defective in EPS synthesis induced almost empty nodules inefficient in nitrogen fixation. Additionally, the ros $R$ mutant produced 3-fold less EPS and elicited significantly fewer nodules, which were occupied by ten times fewer bacteria than the wild-type strain (Janczarek et al. 2009a, 2010). The part-after-part estimation of the several enzymatic as well as non-enzymatic biochemical and physiological features of the wild-type and the pssA and $\operatorname{ros} R$ mutants cultured under oxidative stress conditions confirmed the crucial role of these genes involved in EPS synthesis in oxidative stress defence mechanisms. It was observed that the changes in amounts of EPS in rhizobial strains exerted a negative effect on their oxidative stress response and symbiotic efficiency. The results obtained suggest that the lack of or a significantly decreased level of EPS in the pssA and rosR mutants, respectively, resulted in overproduction of enzymatic antioxidants in order to compensate for the lack of appropriate amounts of EPS, which has a significant protective role against environmental stress conditions. Unfortunately, the high activity of SOD and CAT enzymes resulting in excessive elimination of SOR and $\mathrm{H}_{2} \mathrm{O}_{2}$ is most probably the cause of low effectiveness of symbiosis in the wild-type strain in these stress conditions. Recently, Davies and Walker (2007) identified novel $S$. meliloti mutants compromised for oxidative stress protection and symbiosis, which were sensitive to $\mathrm{H}_{2} \mathrm{O}_{2}$ and symbiotically defective on $M$. sativa. These mutations affected a wide variety of cellular processes, including succinoglycan synthesis. Similarly, D'Haeze and others (2004) indicated that ORS571-X15 mutant of Azorhizobium caulinodans producing significantly less EPS than the wild-type strain was more sensitive to $\mathrm{H}_{2} \mathrm{O}_{2}$ and elicited only pseudo-nodules on its host plant, Sesbania rostrata. Their studies demonstrated a negative correlation between the amount of $\mathrm{H}_{2} \mathrm{O}_{2}$ present within bacteria and the quantity of produced EPS. A protective role of EPS was also shown in ex planta experiments. Therefore, the authors proposed that this polymer forms a diffusion barrier to protect rhizobial cells against huge amounts of $\mathrm{H}_{2} \mathrm{O}_{2}$ encountered during early stages of legume infection and nodule development (D'Haeze et al. 2004). Additionally, the data presented in this work indicate that EPS added to cultures of the $p s A$ and $\operatorname{ros} R$ mutants improves survival of these bacteria in the presence of the prooxidants to levels near to those observed for the wild-type bacteria (Table 2). This suggests that although mutations in both rosR and pss $A$ genes have pleiotropic effects in $R$. leguminosarum bv. trifolii, the lack of EPS surrounding rhizobial cells seems to be a main cause of decreased survival and adaptation ability of these bacteria to stress conditions.

A very important phase in the infection of clover roots by $R$. leguminosarum bv. trifolii leading to effective nodule formation is movement of bacteria inside root hairs (Mateos et al. 1992). This step requires degradation of polysaccharides building the root cell walls by hydrolytic enzymes such as PEC or/and $\beta$-GLU. Mateos and co-workers (1992) confirmed the presence of cell-associated pectinolytic and cellulolytic enzymes in $R$. leguminosarum bv. trifolii. We have observed a stimulation effect of the prooxidants on the extracellular 
PEC and $\beta$-GLU activities for the wild-type $R$. leguminosarum bv. trifolii as well as the pss $A$ and $\operatorname{ros} R$ mutants. The increased amounts of the described enzymes detected under oxidative stress conditions can be interesting from the biotechnological point of view. Special attention is focused on the enzymatic pattern of the rosR mutant, which differs significantly from those of the wild-type and pss $A$ mutant strains (Fig. 7). Previously, we have established that the transcriptional regulator RosR of $R$. leguminosarum bv. trifolii positively regulates the pssA expression (Janczarek and Skorupska 2007; Janczarek and Urbanik-Sypniewska 2013). This gene encodes a protein, which besides its enzymatic activity is probably involved additionally in other cellular processes (Janczarek and Skorupska 2003). Bittinger and Handelsman (2000) have reported that RosR of Rhizobium etli regulates expression of many genes, including those involved in polysaccharide production, carbohydrate metabolism, and plant infection.

Acknowledgments This work was partially supported by the grant of the Rector of Marie Curie-Sklodowska University and the grant of the National Centre of Science no. DEC-2012/07/B/NZ1/ 00099. The microscopic analyses were done using Olympus SV1000 purchased from the funds of the project no. POPW.01.03.00-06-010/09-00 Operational Program Development of Eastern Poland 2007-2013, Priority Axis I, Modern Economy Operations 1.3 Innovations Promotion.

Open Access This article is distributed under the terms of the Creative Commons Attribution License which permits any use, distribution, and reproduction in any medium, provided the original author(s) and the source are credited.

\section{References}

Aebi H (1984) Catalase in vitro. Methods Enzymol 105:121-124 Baron C, Zambryski PC (1995) The plant response in pathogenesis, symbiosis, and wounding: variations on a common theme? Ann Rev Genet 29:107-129

Bayer WF, Fridovich I (1987) Assaying for superoxide dismutase activity: some large consequence of minor changes in conditions. Anal Biochem 161:559-566

Beauchamp C, Fridovich I (1970) Superoxide dismutase improved assays and an assay applicable to acrylamide gels. Anal Biochem 44:276-287

Bittinger MA, Handelsman J (2000) Identification of genes in the RosR regulon in Rhizobium etli. J Bacteriol 182:1706-1713

Bradford MM (1976) A rapid and sensitive method for the quantification of microgram quanties of protein utilizing the principle of protein-dye binding. Anal Biochem 72:248-254
Cheng HP, Walker GC (1998) Succinoglycan is required for initiation and elongation of infection threads during nodulation of alfalfa by Rhizobium meliloti. J Bacteriol 180:51835191

Corticeiro CS, Lima AIG, Figueira EMAP (2006) The importance of glutathione in oxidative status of Rhizobium leguminosarum biovar viciae under $\mathrm{Cd}$ exposure. Enzym Microb Technol 40:132-137

D’Haeze W, Glushka J, De Rycke R, Holsters H, Calson RW (2004) Structural characterization of extracellular polysaccharides of Azorhizobium caulinodans and importance for nodule initiation on Sesbania rostrata. Mol Microbiol 52: 485-500

Davies BW, Walker GC (2007) Disruption of sitA compromises Sinorhizobium meliloti for manganese uptake required for protection against oxidative stress. J Bacteriol 189:21012109

Dombrecht B, Heusdens C, Beullens S, Verreth C, Mulkers E, Proost P, Vanderleyden J, Michiels J (2005) Defence of Rhizobium etli bacteroids against oxidative stress involves a complexly regulated atypical 2-Cys peroxiredoxin. Mol Microbiol 55:1207-1221

Downie JA (2010) The roles of extracellular proteins, polysaccharides and signals in the interactions of rhizobia with legume roots. FEMS Microbiol Rev 34:150-170

Gamero-Sandemetrio E, Gomez-Pastor R, Matallana E (2013) Zymogram profiling of superoxide dismutase and catalase activities allows Saccharomyces and nonSaccharomyces species differentiation and correlates to their fermentation performance. Appl Microbiol Biotechnol 97:4563-4576

Gibson KE, Kobayashi H, Walker GC (2008) Molecular determinants of a symbiotic chronic infection. Ann Rev Genet 42: 413-441

Hérouart D, Sigaud S, Moreau S, Frendo P, Touati D, Puppo A (1996) Cloning and characterization of the katA gene of Rhizobium meliloti encoding a hydrogen peroxide-inducible catalase. J Bacteriol 178:6802-6809

Hérouart D, Baudouin E, Frendo P, Harrison J, Santos R, Jamet A, van de Sype G, Touati D, Puppo A (2002) Reactive oxygen species, nitric oxide and glutathione: a key role in establishment of the legume-Rhizobium symbiosis? Plant Physiol Biochem 40:619-624

Jamet A, Sigaud S, Van de Sype G, Puppo A, Hérouart D (2003) Expression of the bacterial catalase genes during Sinorhizobium meliloti - Medicago sativa symbiosis and their crucial role during infection process. Mol PlantMicrobe Interact 16:217-225

Jamet A, Kiss E, Batut J, Puppo A, Hérouart D (2005) The katA catalase gene is regulated by OxyR in both freeliving and symbiotic Sinorhizobium meliloti. J Bacteriol 187:376-381

Jamet A, Mandon K, Puppo A, Hérouart D (2007) $\mathrm{H}_{2} \mathrm{O}_{2}$ is required for optimal establishment of Medicago satival Sinorhizobium meliloti symbiosis. J Bacteriol 187:87418745

Jamieson DJ (1998) Oxidative stress response of the yeast Saccharomyces cerevisiae. Yeast 14:1511-1527

Janczarek M (2011) Environmental signals and regulatory pathways that influence exopolysaccharide production in rhizobia. Int J Mol Sci 12:7898-7933 
Janczarek M, Skorupska A (2003) Exopolysaccharide synthesis in $R$. leguminosarum bv. trifolii is related to various metabolic pathway. Res Microbiol 154:433-442

Janczarek M, Skorupska A (2007) The Rhizobium leguminosarum bv. trifolii RosR transcriptional regulator involved in exopolysaccharide production. Mol Plant-Microbe Interact $20: 867-881$

Janczarek M, Skorupska A (2011) Modulation of rosR expression and exopolysaccharide production in Rhizobium leguminosarum bv. trifolii by phosphate and clover root exudates. Int J Mol Sci 12:4132-4155

Janczarek M, Urbanik-Sypniewska T (2013) Expression of the Rhizobium leguminosarum bv. trifolii pssA gene involved in exopolysaccharide synthesis is regulated by RosR, phosphate, and the carbon source. J Bacteriol 195:3412-3423

Janczarek M, Jaroszuk-Ściseł J, Skorupska A (2009a) Multiple copies of rosR and pssA genes enhance exopolysaccharide production, symbiotic competitiveness and clover nodulation in Rhizobium leguminosarum bv. trifolii. Anton Leeuw Int $\mathrm{J}$ G 96:471-486

Janczarek M, Kalita M, Skorupska AM (2009b) New taxonomic markers for identification of Rhizobium leguminosarum and discrimination between closely related species. Arch Microbiol 191:207-219

Janczarek M, Kutkowska J, Piersiak T, Skorupska A (2010) Rhizobium leguminosarum bv. trifolii rosR is required for interaction with clover, biofilm formation and adaptation to the environment. BMC Microbiol 10:284

Kawasaki L, Aguirre J (2001) Multiple genes are differentially regulated in Aspergillus nidulans. J Bacteriol 183:1434-1440

Kopcińska J (2009) Localization of reactive oxygen species during symbiosis of early clover and Rhizobium leguminosarum bv. trifolii. Acta Biol Cracov Ser Bot 51:93-98

Krehenbrink M, Edwards A, Downie JA (2011) The superoxide dismutase SodA is targeted to the periplasm in a SecAdependent manner by a novel mechanism. Mol Microbiol 82:164-179

Lloyd JB, Whelan WJ (1969) An improved method for enzymatic determination of glucose in the presence of maltose. Anal Biochem 30:467-470

Lum MR, Hirsch AM (2003) Roots and their symbiotic microbes: strategies to obtain nitrogen and phosphorous in a nutrient-limiting environment. J Plant Growth Regul 21:368-382

Malarczyk E (1989) Transformation of phenolic acid by Nocardia. Acta Microbiol Pol 38:45-53

Matamoros MA, Dalton DA, Ramos J, Clemente MR, Rubio MC, Becana M (2003) Biochemistry and molecular biology of antioxidants in the Rhizobia legume symbiosis. Plant Physiol 133:499-509

Mateos PF, Jimenez-Zurdo JI, Chen J, Squartini AS, Haack SK, Martinez-Molina E, Hubbel DH (1992) Cell-associated pectinolytic and cellulolytic enzymes in Rhizobium leguminosarum bv. trifolii. Appl Environ Microbiol 58: 1816-1822

Mathis R, Van Gijsengem F, De Rycke R, D' Haeze W, Van Maelsaeke E, Anthonio E, Van Montagu M, Holsters M, Vereecke D (2005) Lipopolysaccharides as a communication signal for progression of legume endosymbiosis. Proc Natl Acad Sci U S A 102:2655-2660
McCormick ML, Buettner GR, Britigan BE (1998) Endogenous superoxide dismutase levels regulate iron-dependent hydroxyl radical formation in Escherichia coli exposed to hydrogen peroxide. J Bacteriol 180:622-625

McIntyre HJ, Davies H, Hore TA, Miller SH, Dufour J-P, Ronson CW (2007) Trehalose biosynthesis in Rhizobium leguminosarum bv. trifolii and its role in desiccation tolerance. Appl Environ Microbiol 73:3984-3992

Mitchell RE, Frey EJ, Benn MK (1986) Rhizobitoxine and 1-threo-hydroxythreonine production by the plant pathogen Pseudomonas andropogonis. Phytochem 25:27112715

Nakayama M, Nakajima-Kambe T, Katayama H, Higuchi K, Kawasaki Y, Nakayama RF (2008) High catalase production by Rhizobium radiobacter strain 2-1. J Biosci Bioeng 106: 554-558

Orikasa Y, Nodasaka Y, Ohyama T, Okuyama H, Ichise N, Yumoto I, Morita N, Wei M, Ohwada T (2010) Enhancement of the nitrogen fixation efficiency of genetically-engineered Rhizobium with high catalase activity. J Biosci Bioeng 4:397-402

Pauly N, Pucciariello C, Mandon K, Innocenti G, Jamet A, Boudoin E, Hérouart D, Frendo P, Puppo A (2006) Reactive oxygen and nitrogen species and glutathione: key players in the legume -Rhizobium symbiosis. J Exp Bot 57: 1769-1776

Paździoch-Czochra M, Malarczyk E, Sielewiesiuk J (2003) Relationship of demethylation processes to veratric acid concentration and cell density in cultures of Rhodococcus erythropolis. Cell Biol Int 27:325-336

Perez FJ, Rubio S (2006) An improved chemiluminescence method for hydrogen peroxide determination in plant tissues. Plant Growth Reg 48:89-95

Ramu SK, Peng HM, Cook DR (2002) Nod factor induction of reactive oxygen species production is correlated with expression of the early nodulin gene ripl in Medicago truncatula. Mol Plant-Microbe Interact 15:522-528

Rapoport R, Hanukoglu I, Sklan D (1994) A fluorimetric assay for hydrogen pyroxide, suitable for NAD $(\mathrm{P}) \mathrm{H}$ - dependent superoxide generating redox systems. Anal Biochem 218:309313

Rolfe BG, Carlson RW, Ridge RW, Dazzo RW, Mateos FB, Pankhurst CE (1996) Defective infection and nodulation of clovers by exopolysaccharide mutants of Rhizobium leguminosarum bv. trifolii. Aust J Plant Physiol 23:285-303

Rubio MC, James EK, Clemente MR, Bucciarelli B, Delledonne M (2004) Localization of superoxide dismutases and hydrogen peroxide in legume root nodules. Mol Plant-Microbe Interact 17:1294-1305

Saenkham P, Eiamphungporn W, Farrand SK, Vattanaviboon P, Mongkolsuk S (2007) Multiple superoxide dismutase in Agrobacterium tumefaciens: functional analysis, gene regulation and influence on tumorigenesis. J Bacteriol 189:88078817

Sambrook J, Fitsch EF, Maniatis T (1989) Molecular cloning. A laboratory manual. Cold Spring Harbor Press, Cold Spring Harbor

Santos R, Bocquet S, Puppo A, Touati D (1999) Characterization of an atypical superoxide dismutase from Sinorhizobium meliloti. J Bacteriol 181:4509-4516 
Santos R, Herouart D, Puppo A, Touati D (2000) Critical protective role of bacterial superoxide dismutase in Rhizobiumlegume symbiosis. Mol Microbiol 38:750-759

Santos R, Hérouart D, Siguad S, Touati D, Puppo A (2001) Oxidative burst in alfalfa-Sinorhizobium meliloti symbiotic interactions. Mol Plant-Microbe Interact 14:86-89

Schliebs W, Würtz C, Wolf-Hubert K, Veenhuis M, Rottensteiner H (2006) A eukaryote without catalase-containing microbodies: Neurospora crassa exhibits a unique cellular distribution of its four catalases. Eucaryot Cell 5:1490-1502

Vincent JM (1970) A manual for the practical study of root nodule bacteria. In: International Biological Program handbook no 15. Blackwell Scientific Publications, Ltd, Oxford
Wadsworth GJ, Scandalios JG (1990) Molecular characterization of catalase null allele at the Cat3 locus in maize. Genetics 125:867-872

Warm E, Laties GG (1982) Quantification of hydrogen peroxide in plant extracts by the chemiluminescence reaction with luminal. Phytochem 21:827-831

Wayne LG, Diaz GA (1986) A double staining method for differentiating between two classes of mycobacterial catalase in polyacrylamide electrophoresis gels. Anal Biochem 157:89-92

Yuan Z, Zaheer R, Finan TM (2005) Phosphate limitation induces catalase expression in Sinorhizobium meliloti, Pseudomonas aeruginosa and Agrobacterium tumefaciens. Mol Microbiol 58:877-894 